\title{
Complex Determinants of Epithelial: Mesenchymal Phenotypic Plasticity in Ovarian Cancer
}

\author{
Yuliya Klymenko ${ }^{1,2}$, Oleg Kim ${ }^{3,4}$ and M. Sharon Stack ${ }^{1, *}$ \\ 1 Department of Chemistry and Biochemistry, Harper Cancer Research Institute, University of Notre Dame, \\ Notre Dame, IN 46617, USA; yklymenk@nd.edu \\ 2 Medical Sciences Program, Indiana University School of Medicine, Bloomington, IN 47405, USA \\ 3 Department of Applied and Computational Mathematics and Statistics, Harper Cancer Research Institute, \\ University of Notre Dame, Notre Dame, IN 46617, USA; okim@nd.edu \\ 4 Department of Mathematics, University of California Riverside, Riverside, CA 92521, USA \\ * Correspondence: sstack@nd.edu; Tel.: +1-574-631-4100
}

Received: 9 June 2017; Accepted: 6 August 2017; Published: 9 August 2017

\begin{abstract}
Unlike most epithelial malignancies which metastasize hematogenously, metastasis of epithelial ovarian cancer (EOC) occurs primarily via transcoelomic dissemination, characterized by exfoliation of cells from the primary tumor, avoidance of detachment-induced cell death (anoikis), movement throughout the peritoneal cavity as individual cells and multi-cellular aggregates (MCAs), adhesion to and disruption of the mesothelial lining of the peritoneum, and submesothelial matrix anchoring and proliferation to generate widely disseminated metastases. This exceptional microenvironment is highly permissive for phenotypic plasticity, enabling mesenchymal-to-epithelial (MET) and epithelial-to-mesenchymal (EMT) transitions. In this review, we summarize current knowledge on EOC heterogeneity in an EMT context, outline major regulators of EMT in ovarian cancer, address controversies in EMT and EOC chemoresistance, and highlight computational modeling approaches toward understanding EMT/MET in EOC.
\end{abstract}

Keywords: ovarian cancer; intraperitoneal metastasis; cadherins; heterogeneity; epithelial-tomesenchymal transition (EMT); mesenchymal-to-epithelial transition (MET); intraperitoneal tumor microenvironment; computational modeling of EMT

\section{Introduction}

Most epithelial carcinomas disseminate via the bloodstream or lymphatic system, utilizing a classical invasion-metastasis cascade mechanism which involves the local invasion of primary tumor epitheliocytes into the surrounding stroma and extracellular matrix (ECM), intravasation and transport through blood/lymph vessels, arrest at distant organ sites, extravasation into the organ parenchyma, and subsequent proliferation to form micro- and macro-metastases [1-5]. The triggering and ultimate success of these events depends on the epithelial-to-mesenchymal transition (EMT) and its key players, E-cadherin (epithelial, Ecad) [6] and N-cadherin (neural, Ncad) [7]-calcium-dependent transmembrane adhesion molecules which are responsible for maintaining cell-cell junctions between adjacent cells, thereby regulating the epithelial integrity and tissue architecture. During EMT, epithelial-type cancer cells undergo a set of molecular, morphological and functional changes with the loss of Ecad and gain of Ncad, which result in impaired epithelial cell-cell junctions and cell polarity, acquisition of a mesenchymal motile cell phenotype, and labile bonding with Ncad-expressing fibroblasts [8,9], endothelial cells and pericytes $[10,11]$. These changes facilitate cancer cell migration through stromal tissue, intravasation, and dissemination throughout the organism. The opposite process, designated mesenchymal-to-epithelial transition (MET), includes reverse cadherin switching (Ncad inhibition 
and Ecad re-expression) and often occurs at the secondary metastatic site, allowing for anchored and extravasating cancer cells regain epithelial features and proliferate into larger tumor nodules [2,3,12].

Epithelial ovarian cancer (EOC) is the deadliest gynecological malignancy, which stably ranks fifth highest among cancer deaths for women, and the American Cancer Society predicts that 14,080 women will die from ovarian cancer in $2017[13,14]$. The high mortality is primarily due to detection at late stages of the disease with vast intra-peritoneal dissemination [15] and to development of drug resistance after initial good response to treatment [16]. As opposed to other malignancies which progress through the above described canonical hematogenous invasion-metastasis cascade, EOC undertakes a distinct transcoelomic route of spread (through peritoneum-covered surfaces and organs of the abdominal and pelvic cavity), expanding via direct extension of cancer cells from the primary tumor into the intra-abdominal fluid-filled space, where they survive and travel as single cells and multi-cellular aggregates (MCAs) with the peritoneal fluid flow, subsequently adhering to peritoneal tissues, migrating into sub-mesothelial matrix and forming secondary lesions [17-19]. Recently, metastatic spreading of EOC via lymphatic [20] and blood [21,22] systems in vivo were reported. Nevertheless, the proposed new hematogenous models of EOC metastasis further highlight the involvement of the ovary in this process, as oophorectomy resulted in a complete abruption of peritoneal metastases and ascites development in mice [22]. These data suggest that, even in the case of hematogenous EOC cell circulation, metastatic EOC cells home to the ovary prior to further harnessing a predominantly intraperitoneal dissemination mechanism.

Hematogenously metastasizing solid tumors must first invade the tumor stroma and access the vasculature, necessitating an early EMT in order to adopt a motile, invasive phenotype. In contrast, the unique transcoelomic route of EOC dissemination generates an exceptional microenvironment quite distinct from most solid tumors, as cells are exfoliated directly into the peritoneal cavity. Thus, early events in metastatic dissemination do not require a mesenchymal phenotype. Alternatively, EOC exhibits phenotypic plasticity with regard to cadherin switching and exhibits significant cadherin heterogeneity during metastasis. In this review we focus on the peculiarities of the EMT/MET process in ovarian carcinoma, discuss tumor site-of-origin as a premise for EOC epithelial/mesenchymal heterogeneity, assess the potential clinical relevance of this plasticity, outline established and potential mediators of EMT/MET in EOC, and share our thoughts on possible future directions for EMT research.

\section{EOC Cell of Origin: A Current Controversy}

\subsection{Ovarian Surface Epithelum Origin}

It was widely accepted for years that EOC arises from transformation of the normal ovarian surface epithelium (OSE), a mesodermally derived and hormone-dependent single cell layer that covers the ovary (Figure 1). The OSE regularly undergoes cycles of rupture and repair associated with ovulation and thereby flexibly shifts between mesenchymal and epithelial phenotypes in response to the need for migration and proliferation to regenerate the intact epithelial surface [23]. The normal OSE exhibits flat morphology with high expression of mesenchymal markers (Ncad, calretinin, mesothelin) and absence of epithelial markers (Ecad, EpCAM, EMA, OVGP1 and ciliary bodies) [24]. Conversion of OSE towards a cuboidal/columnar phenotype, indicative of tubal metaplasia of the OSE, is accompanied by acquisition of epithelial markers (Ecad, EpCAM, OVGP1, ciliary bodies) and suppression of mesenchymal markers (modestly downregulated Ncad and fully abrogated calretinin); alterations also characteristic of MET [24]. Among pathogenic factors suggested to initiate OSE metaplasia and malignant transformation is presence of inclusion cysts. The uneven ovarian surface contains invaginations and inclusion cysts that lead to overcrowding of OSE in these regions. Adaptation to a cuboid epithelial-like shape in these regions with accompanying metaplastic changes can then occur [25]. OSE cells trapped inside the inclusion cysts are more exposed to growth factors which may provide additional cues for neoplastic progression. OSE may also launch autocrine mechanisms 
through the release of hormones and cytokines [23]. Alternatively, OSE may undergo metaplasia to acquire Müllerian duct features with subsequent neoplastic progression to tumor formation [23].

\section{Putative EOC origins}

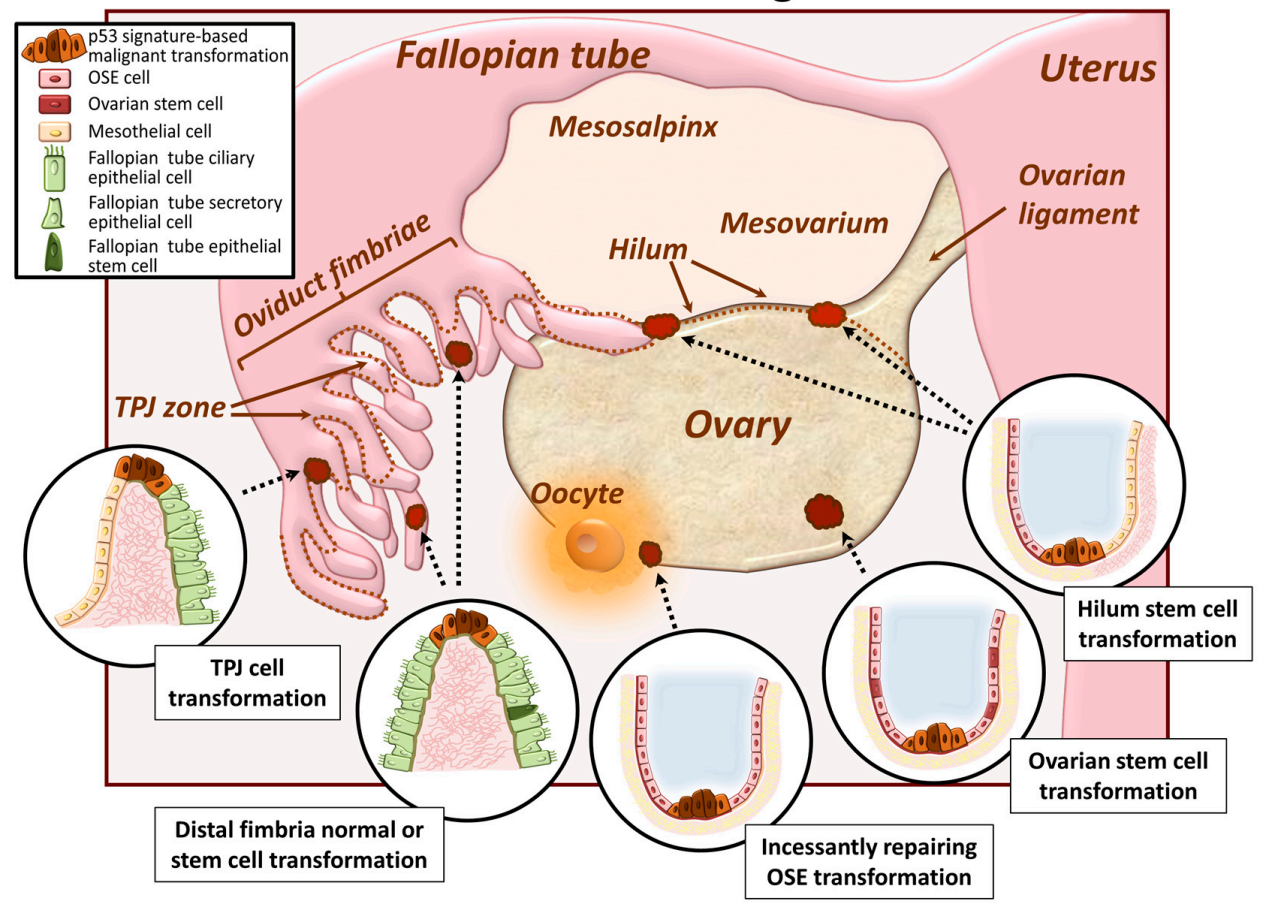

Figure 1. Putative epithelial ovarian cancer (EOC) origins. Represented is a schematic of the female reproductive system and the potential sites for ovarian cancer initiation. In the ovary, EOC may arise from the neoplastic conversion of the normal ovarian surface epithelium (OSE), as a result of frequent ovulatory rupture and post-ovulatory healing accompanied by transitions between mesenchymal and epithelial cell phenotypes; from malignantly transformed ovarian stem cells residing on the ovarian surface; or from the hilum, a translational zone between the ovary and mesothelium (and to some extent oviduct fimbriae), that contains cells with stem cell properties and propensity to tumorigenesis. In the fallopian tube, EOC may arise from the normal or stem-like cells in the distal fimbria actively participating in reproductive function-related fimbria injury; or from the tubal-peritoneal junction (TPJ), a region connecting mesothelium and oviductal fimbriae mucosa, often comprising translational metaplasia changes.

\subsection{Oviduct Fimbriae Epithelium Origin}

In recent years, the epithelium of the distal fimbriae of the fallopian tube has been recognized as a potential site of origin of ovarian cancer (Figure 1). It is a pseudo-stratified columnar cell monolayer comprised of secretory and ciliated cells and exhibits both epithelial (high levels of Ecad, EpCAM, EMA, OVGP1) and mesenchymal markers (ubiquitous expression of Ncad and vimentin, and varying/absent expression of calretinin and mesothelin) [24,26]. Specifically, serous tubal intra-epithelial carcinoma (STIC), developed via acquisition of a p53 signature in a distal oviduct fimbriae tumor-initiating cell, is considered to be the site of tumor initiation, while tumors on the ovary and peritoneal surfaces are thought to be secondary lesions [27-32]. This hypothesis is supported by the fact that to date no premalignant lesions for ovarian carcinoma has yet been established. Furthermore, STICs can be found in patients without ovarian cancer, while ovarian and peritoneal malignancies are often associated with the presence of STIC [33]. Other aspects supporting this notion include the close physical proximity of the tube distal fimbria to the ovarian surface and the high frequency of identical p53 mutations in STICs and high grade serous adenocarcinomas [33]. Comprehensive analyses specifically focusing 
on accumulating evidence in support of both OSE and tubal fimbriae as sources of EOC initiation are published elsewhere [26,34].

\subsection{Ovarian and/or Tubal Stem Cell Transformation}

Recent findings propose stem cell transformation as a potential cause of ovarian cancer initiation (Figure 1) [35]. It has been postulated that ovarian carcinomas are heterogeneous tumors and contain a small number of cells with stem cell-like characteristics that express specific stem cell markers [35]. Retrieved from patient ascites, ovarian cancer cells positive for stem cell-related molecules (such as Oct4, Nestin, and Nanog) exhibit growth in an anchorage-independent manner in vitro and present serial metastatic tumors in vivo [35]. A large gene expression profiling study of normal OSE samples and patient-derived tissues from serous papillary adenocarcinoma patients revealed that a substantial pool of OSE cells are not fully differentiated (multipotent) and retain the capacity to serve as ovarian cancer initiating cells [36]. This side population of cells was identified and characterized from distinct genetically engineered mouse ovarian cancer cell lines, and showed the ability to efflux the DNA-binding dye Hoechst 33342, formed measurable tumors more rapidly and were less sensitive to the chemotherapeutic agent doxorubicin when compared with non-side population cells $[18,37]$. The detection of ovarian carcinoma stem cells with an ability to self-renew and high epithelial plasticity raises the interesting possibility that these cells have higher metastatic efficiency and may be responsible for the majority of metastasizing ovarian carcinoma cells [18]. Recently, a cancer-prone ovarian cancer stem cell niche was identified [38]. It constitutes the hilum region of the ovary, a translational (or junctional) area between the OSE, mesothelium and tubal (oviductal) epithelium [38]. The hilum region contains a large population of slowly cycling cells that express stem and progenitor cell markers and demonstrate a high propensity to malignant transformation [38]. Another possible "hot spot for carcinogenesis" was identified in a study that characterized the tubal-peritoneal junction (TPJ, a zone where peritoneal mesothelium and oviductal fimbria mucosa meet) with regions of translational metaplasia [39]. Finally, fallopian tube epithelium stem-like cells, lacking markers of ciliated or secretory differentiation, were isolated at the distal (fimbriated) end of the fallopian tube, at the site of frequent, reproductive function-associated fimbria injury, and may also serve as a starting point for EOC carcinogenesis [40]. An elegant report illustrating current knowledge about ovarian and tubal epithelium stem-like cells, their molecular properties and cell niches is published in [41].

\section{Phenotypic Heterogeneity and Relevance of Intraperitoneally Residing Cells/MCAs}

As described above, tumors classified as ovarian cancer can arise from histologically and molecularly distinct neoplastic progenitors: either from mesenchymal-type OSE that has undergone metaplastic MET changes; from the highly differentiated columnar fallopian tube epithelum which contains both epithelial (predominantly) and mesenchymal (moderately) traits; or from a variety of ovarian surface, oviductal fimbriae or junctional area-localized stem-like precursors which may diversely express epithelial, mesenchymal and stem cell markers. Given the unique intraperitoneal metastasis mode and the diversity of progenitors, it is not surprising that malignant ascites contains a heterogeneous pool of individual and clustered (as MCAs) free-floating metastatic units within the peritoneal cavity $[17,42-44]$. Furthermore, mechanisms that regulate metastatic MCA formation are currently unknown, however options include exfoliation of single cells from the primary tumor followed by association into aggregates; exfoliation of cell-cell adherent sheets from the primary tumor that subsequently condense into MCAs; or through proliferation of individual cells in suspension into aggregates.

The implications of the clinically observed epithelial, mesenchymal and intermediate cell phenotypes are a subject of continued active investigation. Recent studies show that ovarian cancer cell metastatic properties, aggregation dynamics, MCA surface morphology, inner ultrastructure and behavior differ among epithelial, intermediate and mesenchymal phenotypes and are regulated by E- and Ncad expression both in their free-floating state [43] and at the secondary metastatic site [45]. 
It has been reported that mesenchymal-type EOC cells tend to aggregate into very compact solid spheroids, whereas epithelial-type EOC form loose and easily disaggregated MCAs [43], and these properties are modulated by shifts in E- and $\mathrm{N}$-cadherin expression. These findings are interesting in the content of MCA survival and chemosensitivity, as such differences in aggregate cohesivity may drive distinct responses of epithelial and mesenchymal MCAs to hypoxic conditions, glucose starvation, and drug penetration to cells in the MCA core.

\subsection{Mesenchymal Phenotype}

A recent study [45] delineated that within a mixed population of EOC cells and MCAs, only mesenchymal cells and mesenchymal cell-containing aggregates exhibit the ability to invade through 3-dimensional (3D) collagen-rich matrices. Moreover, this process relies on competent Ncad cell-cell junctions and can be successfully blocked by N-cadherin antagonists. Overexpression of Ncad also stimulated mesothelial cell clearance by cancer MCAs [45]. These findings may provide a partial explanation for differential metastatic efficiency among various ovarian cancer cell lines in murine models. Epithelial type ovarian cancer cells, such as OvCa433, do not readily form intraperitoneal tumor xenografts [46], and in vivo growth of this cell line is limited to subcutaneously injected regions [47]. Meanwhile, mesenchymal-type (Ncad+) cell lines easily create large numerous widely-disseminated metastatic lesions in vivo, often accompanied by cancerous cachexia and ascites in mice [48-50]. An immunoblot analysis of two metastatically successful EOC cell lines (SKOV3 and OVCAR8) and their highly metastatic in vivo-selected intraperitoneal (ip) derivatives (SKOV3ip and OVCAR8ip), revealed elevated Ncad in the absence of Ecad in aggressive ip sublines (Figure 2). This is similar to data obtained from analysis of primary tumors and patient-matched metastatic lesions, wherein enhanced Ncad expression is observed in metastases relative to the corresponding primary tumor [17]. Together these data suggest that intraperitoneal delivery of Ncad blocking molecules could be beneficial for suppressing development of metastatic lesions. Moreover, given that EMT is often a reversible process, selective targeting of EMT mediators to induce a MET program in mesenchymal-type EOC cells [12] may become potentially advantageous against peritoneal lesion formation.
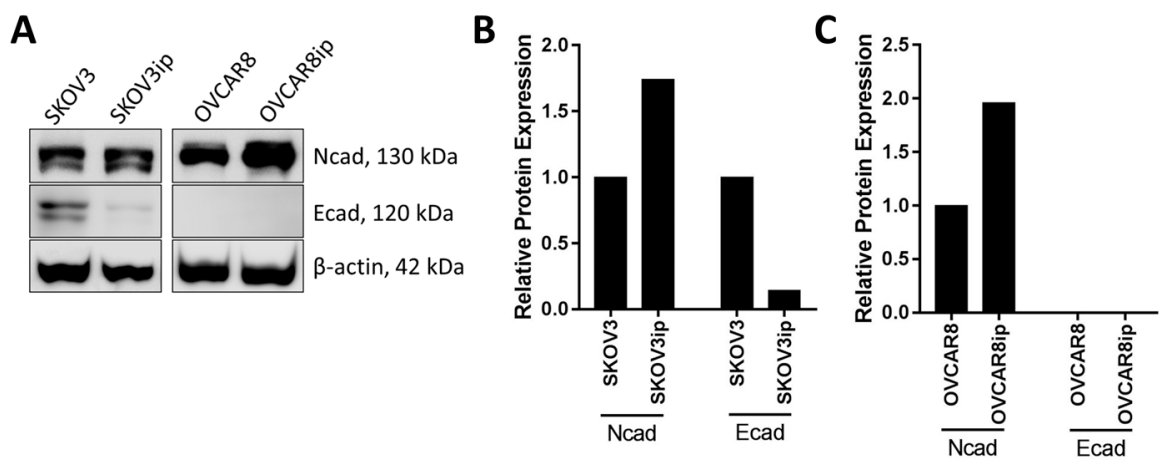

Figure 2. Cadherin expression alterations in human EOC cell lines and their highly metastatic derivatives. (A) Ecad and Ncad expression in parental SKOV3 and OVCAR8 cells and their matching highly metastatic derivatives, SKOV3ip and OVCAR8ip (isolated from murine intraperitoneal metastases), was assessed by Western blot analysis with the rabbit monoclonal anti-Ecad (Abcam, 1:1000 dilution) or mouse anti-Ncad (Life Technologies, 1:1000 dilution) primary antibody, respectively, followed by peroxidase-conjugated anti-rabbit or anti-mouse secondary antibody (Sigma-Aldrich, 1:4000 dilution) and enhanced chemiluminescence detection by ImageQuant LAS4000 biomolecular imager. (B,C) The densitometric analysis of immunoblot bands represented in Figure 2A was conducted in ImageJ, and protein expression (band relative intensity) was normalized against $\beta$-actin loading control. 


\subsection{Epithelial Phenotype}

Epithelial phenotype cells may also promote EOC progression. Existing literature suggests that enhanced Ecad expression in early stages of EOC progression is necessary to avoid detachment-induced apoptosis and for resistance to radiation and chemotherapy [51-55]. In agreement with these observations are studies reporting enhanced chemoresistance in EOC cells of epithelial phenotype as compared to mesenchymal phenotype (see Section 5 for further discussion) [56,57]. One the other hand, loss of Ecad is canonically associated with the disruption of adherens junctions, and shedding of the Ecad extracellular domain induced by different bioactive molecules (lysophosphatidic acid, epidermal growth factor, etc.) leads to increased detachment of EOC cells from the tumor surface [23,58-61]. Besides the loss of cell-cell junctions and exfoliation/dissemination of more tumor cells into the peritoneal cavity, the shed Ecad ectodomain retains functional significance and was documented to further disrupt existing cell junctions between EOC cells [62], stimulate cancer cell invasion by triggering signaling pathways [63], and upregulate matrix metalloproteinase (MMP) MMP-2, MMP-9 and membrane type 1 (MT1-MMP) expression [64]. Meanwhile, the freed cytoplasmic domain of Ecad may also potentiate cancer progression via Wnt signaling, as the release of junctional Ecad and $\beta$-catenin leads to nuclear accumulation of soluble $\beta$-catenin and enhanced transcriptional activity [65]. In some cases (as reported for esophageal squamous cell carcinoma), nuclear translocation of the cytoplasmic Ecad fragment can alone promote transcriptional regulation, independently of $\beta$-catenin recruitment [66]. More on the role of Ecad and the functional significance of its cleaved domains is reviewed in $[67,68]$.

\subsection{Intermediate (Hybrid) Phenotype}

It is currently well recognized for many malignancies that cancer cells do not transiently exhibit hybrid epithelial/mesenchymal (E/M) properties, but rather stably maintain a certain level of intermediate (partial EMT, semi-EMT) phenotype [69-72], which provides benefits over purely epithelial or mesenchymal morphological states. As widely reported in literature, the hybrid E/M phenotype allows cells exist dynamically, adjusting their differentiation and functionality in response to the environmental milieu [69,73-76], garner resistance to cell death, radiation and chemotherapeutic agents [69,77-79]. Moreover, multiple studies indicate that in contrast to cells in a finite epithelial or mesenchymal state, hybrid $\mathrm{E} / \mathrm{M}$ cells more readily display stemness properties, such as multipotency and self-perpetuation [80,81], (re)-expression of stem cell markers [76,80,81], sphere formation $[80,82]$ and tumor-initiating potential $[81,82]$. For ovarian cancer in particular, a subset of in vivo tumorigenic cells have been detected in a hybrid E/M state [81], which simultaneously express epithelial, mesenchymal and cancer stem cell markers, and retain the capacity for self-renewal as well as generation of more differentiated progenies. The authors demonstrated that the differentiation fate of the hybrid E/M ovarian cancer cells is associated with EMT pathways and may be regulated by environmental stimuli or the state of adjacent (epithelial or mesenchymal) cells [81]. Similarly, dual cadherin-expressing (intermediate) EOC cell lines OVCAR3 and OvCa432 proliferate to create a heterogeneous mixture containing hybrid Ecad+/Ncad+, predominantly Ecad+ and predominantly Ncad+ progenies within the same subclone, as confirmed by immunostain analysis [43]. Furthermore, the newly generated hybrid Ecad+/Ncad+ subclones exhibit higher proliferation indices in comparison with their parental, purely epithelial or purely mesenchymal EOC cells [43]. Additionally, substratum-free EOC cell aggregation relies on homotypic Ecad:Ecad or Ncad:Ncad interactions; as a consequence, EOC cells in co-culture exhibit the propensity to sort into purely epithelial Ecad-expressing and purely mesenchymal Ncad+ MCAs, whereas hybrid cells presenting both cadherins can form heterogeneous MCAs with all cell phenotypes [43]. This may serve an additional tumor-supporting role through recruitment of these stem-like cells adjacent to fully differentiated cells (e.g., to the metastatic niche together with mesenchymal-type cells or as an apoptosis-resistant component of epithelial-type aggregates). Our current understanding of EOC 
cell/MCA phenotypic heterogeneity, plasticity and the significance for ovarian cancer progression is summarized in Figure 3.

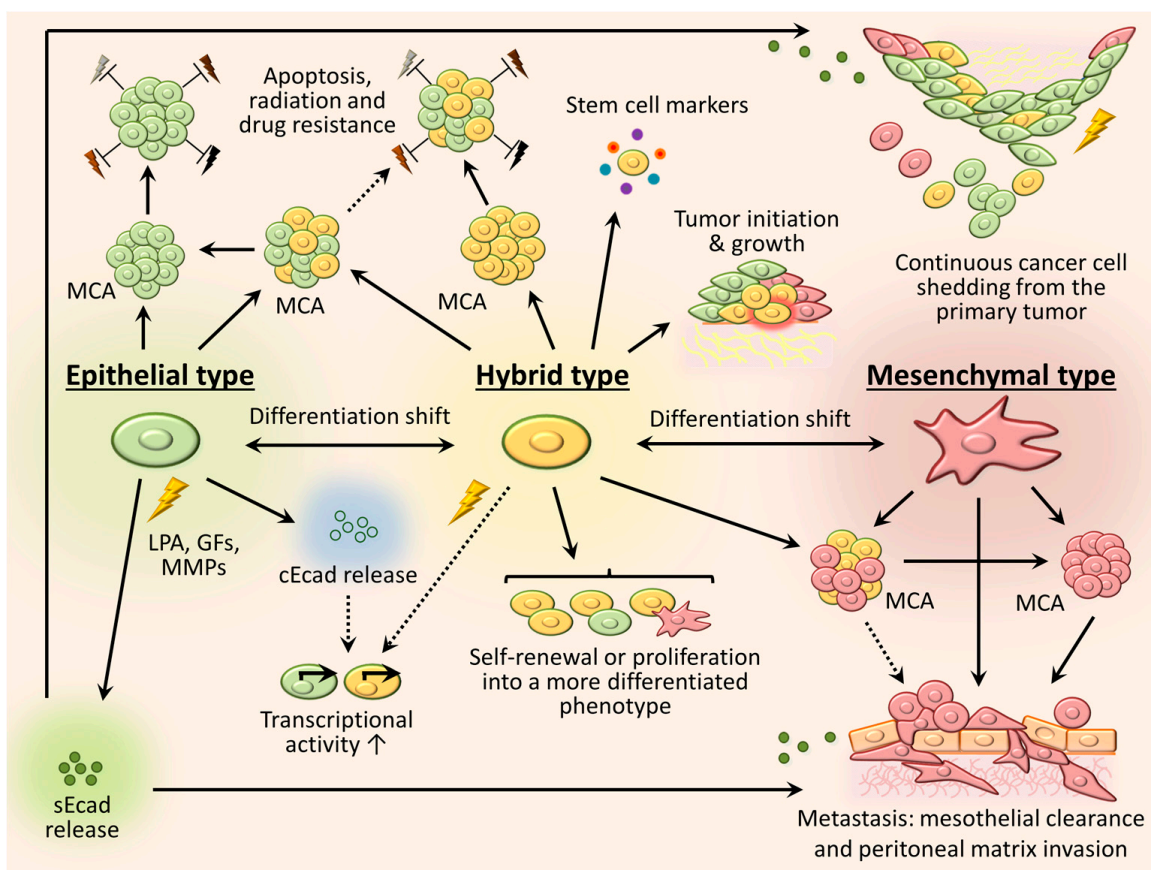

Figure 3. Phenotypic plasticity of EOC cells in the peritoneal cavity. Triggered by the soluble factors abundant in intraperitoneal fluid such as the bioactive lipid lysophosphatidic acid (LPA), growth factors (GFs), and matrix metalloproteinases (MMPs) (all designated as yellow lightening), ovarian cancer cells exist as a heterogeneous mixture of free-floating epithelial, mesenchymal and intermediate (hybrid) cells inside the peritoneal cavity. These cells can dynamically shift between phenotypes along the EMT spectrum adjusting to microenvironmental cues. Multicellular aggregation (MCA) of epithelial-type cells (green) is reported to play a pro-survival role through developing resistance to cell death, radiation and chemotherapeutics (designated grey, brown and black lightening). Bioactive molecules promote cleavage of the Ecad ectodomain to generate a soluble Ecad fragment (sEcad, green filled dots). The sEcad fragment may promote further disruption of cell-cell junctions between the epithelial and hybrid cells and enhance cell shedding from the primary tumor surface. The released Ecad cytoplasmic domain (cEcad, green open dots) may stimulate cell transcriptional activity. Mesenchymal-type cells (pink) readily form MCAs and are predominantly involved in metastasis-associated behaviors, exhibiting mesothelial cell (orange cuboid) clearance activity and peritoneal matrix invasion. Additionally, cell invasion may be amplified by stimuli from sEcad. The hybrid cells (yellow) retain stemness properties: expression of stem cell markers (colored dots), ability for self-renewal or proliferation into a more differentiated phenotype, tumor initiation (tumor-initiating cell designated red-circled) and growth. Hybrid cells may also form mixed MCAs with either epithelial or mesenchymal cells, undergo differentiation consistent with the phenotype of the adjacent cells in co-culture and share their subsequent fate. Black arrows represent interactions reported in ovarian carcinomas; dashed arrows designate patterns that were observed in other cancer types and may potentially be applicable towards ovarian cancer, but require further validation.

\section{Factors Contributing to Dynamic EMT Shifts in Ovarian Cancer Cells}

\subsection{Components of Ascitic Fluid}

While MET processes accompanying ovarian carcinoma initiation usually occur due to genetic alterations (neoplastic metamorphosis built on a p53 signature background as a consequence of incessantly damaged OSE or distal oviduct fimbriae, or vulnerabilities of the translational metaplasia 
regions in the areas of junction between two distinct epithelia), the subsequent shifts along the MET/EMT spectrum in intraperitoneally-residing cells are due not to genetic mutations, but rather occur as a response to a variety of external cues arising from the ascitic microenvironment (Figure 4).

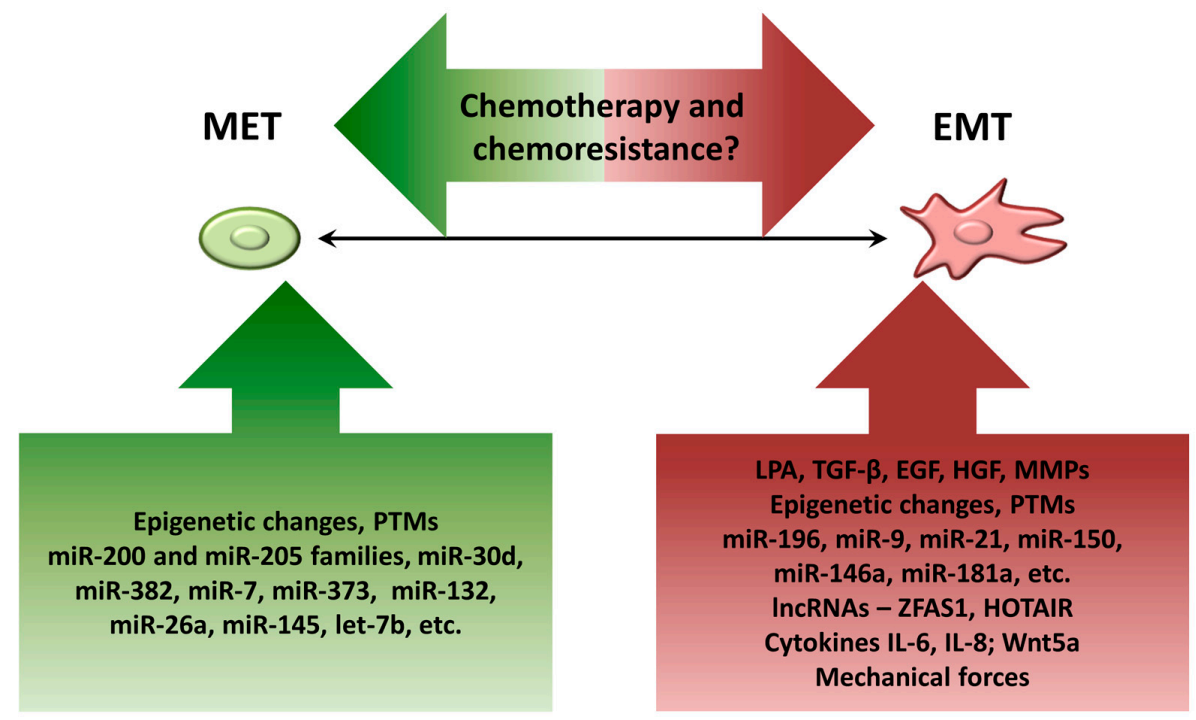

Figure 4. Overview of EMT regulators in ovarian cancer. The diagram summarizes major factors involved in MET (green box) and EMT (red box) programs during EOC progression. The interplay between EMT shifts and ovarian cancer chemotherapy/chemoresistance currently remains controversial.

One of the most well-characterized factors implicated in ovarian carcinogenesis and metastasis is lysophosphatidic acid (LPA), a bioactive lipid molecule which is notably abundant in ascites and plasma of patients with ovarian cancer and activates a subfamily of G-protein coupled cell surface receptors, eliciting a variety of cellular responses such as aberrant proliferation, adhesion, migration, invasion and anoikis-resistance [83-88]. It was shown that LPA is constitutively produced by the mesothelial cells of the peritoneum, increasing EOC cell adhesive, migratory and invasive properties [89]. In the content of EMT, LPA was shown to induce shedding of the $80 \mathrm{kDa}$ extracellular domain of Ecad from EOC cells in a urokinase plasminogen activator (uPA)-dependent manner, disrupting cell-cell junctions and promoting a cellular mesenchymal phenotype with enhanced motility and invasion [63]. Notably, in this work the authors showed that the cleaved soluble Ecad itself also stimulates EOC cell invasion [63]. Additionally, LPA upregulates expression of matrix metalloproteinase-9 (MMP-9) and triggers MMP-9-catalyzed Ecad ectodomain shedding in a concentration- and time-dependent manner, disrupting junctional integrity in ovarian cancer cells and contributing to EMT [60]. Notably, blocking LPA receptors successfully suppressed MMP-9 expression levels and restored EOC cell-cell adhesion [60], suggesting a possible approach for therapeutic intervention. LPA is also involved in reorganization of the actin cytoskeleton, causing rearrangement of stress fibers and cell adhesion together with enhancement of MMP-2 enzymatic activity [90]. MMP-2 activation is enhanced in LPA-treated cells and results in enhanced MMP-dependent migratory and invasive behavior of EOC cells [91]. Following the disruption of cell-cell junctions, LPA also initiates loss of junctional $\beta$-catenin, promotes its nuclear translocation and reinforces the EMT program in ovarian cancer cells via activation of Wnt/ $\beta$-catenin signaling nexus [92]. Recently, LPA was elucidated to stimulate the epithelial-to-mesenchymal switch in ovarian cancer cells via downregulation of SIRT1, an established inactivator of ZEB1 and suppressor of EMT [93]. Additionally, LPA intensifies EMT in ovarian cancer through upregulation of Slug/Snail2 EMT markers via G $\alpha \mathrm{i} 2$, Src, and HIF1 $\alpha$ signaling pathway [94]. 
In addition to LPA, other growth factors, such as epidermal growth factor (EGF), hepatocyte growth factor (HGF), transforming growth factor- $\beta$ (TGF- $\beta$ ), present in ovarian neoplastic microenvironment, are thought to influence EMT by inducing cleavage of Ecad fragments to impair cell-cell cohesion and via enhancing multiple complex signaling networks and transcriptional activity. These studies are described elsewhere [95-98].

Several MMP family members are known to be involved in EMT processes for different types of epithelial cancers, including ovarian carcinomas. Due to their proteolytic activity, multiple MMPs reportedly cause cleavage of the Ecad ectodomain and reorganization of zonula occludens (repression of tight junction protein ZO-1), hence, abrogating cell-cell adhesion, augmenting $\beta$-catenin nuclear translocation and activation of Wnt signaling, boosting acquisition of mesenchymal traits by cancer cells and enhancing cell invasiveness both in vitro and in vivo [60,91,99-103]. The later process is also reinforced due to the well-known role of MMPs in proteolysis and remodeling of diverse components of extracellular matrices [104-106]. Notably, MMP expression and activity may in turn be regulated by EMT-associated factors, such as Snail [107] or $\beta$-catenin [108-110]. More on the diverse effects of MMPs on cancer progression and metastasis, their targets, regulation mechanisms and potential therapeutic implications is discussed in [111-113].

Ovarian cancer cells are also subjected to cytokines and immune cells present in EOC-associated malignant ascites, that may potentially contribute to EMT shifts. In particular, interleukins (IL)-1 $\beta$, IL-6, IL-8 and IL-10 are substantially abundant in ascitic effusions from EOC patients ([114-116] and reviewed in [117]). Notably, the literature reports a pro-EMT role for IL-6 and IL- 8 in ovarian cancer. Attenuated Ecad expression, upregulation of $\beta$-catenin and enhanced SKOV3 and OVCAR3 cell migration in response to IL8 has been demonstrated [118]. Similarly, exposure of EOC and other gynecologic cancer cells to IL-6 treatment mitigates epithelial marker expression and elevates mesenchymal markers expression, increases MMP-2 and MMP-9 activity and avidly enhances migratory and invasive properties [119]. Additionally, IL-6 is known to be involved in EMT shifts, self-renewal, inducing stemness properties in cancer cells and drug resistance (outlined in [120]). Interestingly, production of both IL- 6 and IL-8 is reinforced by LPA through transcriptional activation of IL gene promoters and upregulation of LPA receptors [121]. Evidence for chemokine ligand 5 (CCL-5) and chemokine receptors (CCR)-1/3/5 [122], CCL-19/21 and CCR-7 [123] involvement in EMT events and ovarian carcinoma metastasis have also been reported.

Other bioactive molecules may also participate in the EMT/MET program in EOC. For example, the mucin CA125/MUC16 may be associated with EMT in ovarian cancer due to its binding to Ecad and $\beta$-catenin complexes, as its downregulation results in epithelial-mesenchymal switch (as evidenced by loss of Ecad and cytokeratin-18 and gain of Ncad and vimentin), re-activation of EGFR signaling and increases in MMP-2 and MMP-9 expression and functional activity [124]. Contrary to these results are data [125] demonstrating increased EOC tumor growth, colony formation, cell motility, invasive and metastatic properties upon overexpression of MUC16, accompanied by loss of Ecad and enhancement of Ncad and vimentin expression. Non-canonical Wnt5a signaling is another potential EMT-regulator and has recently been the subject of a comprehensive review [126]. Wnt5a protein is rich in ovarian cancer patients' malignant ascites [126] and its expression is shown to correlate with vascular mimicry and metastatic success [127]. Therefore, additional research to elucidate the role of Wnt5a in EOC progression and metastasis is warranted.

\subsection{Epigenetic Changes}

EMT-related epigenetic changes have been described for many cancers including EOC [128]. Silencing of $\mathrm{CDH} 1$ (Ecad) by promoter hypermethylation takes place in breast, prostate, gastric and urinary bladder cancers [129-131]. Zinc finger E-box-binding homeobox 1 (ZEB1), a known transcriptional repressor of Ecad, can also work epigenetically through recruitment of a DNA methyltransferase 1 (DNMT1) to the CDH1 promoter [132]. Among the most common histone modifications involved in EMT are histone demethylation at the SNAI1 promoter (activate transcription 
of SNAI1), di- or trimethylation at the TWIST promoter (TWIST activation), and histone mono-, di- and trimethylation at the CDH1 promoter by multiple methyltransferases (CDH1 transcription suppression) [128,133-136]. Histone acetylation (recruitment of histone acetyl transferases, HATs, and transcription activation) and deacetylation (recruitment of histone deacetylases, HDACs, and transcription inactivation) are mechanisms often employed for regulation of Ecad expression. SNAI1 and ZEB1 use HDACs for Ecad silencing [137,138]. TWIST recruits a multi-protein complex capable of deacetylation and nucleosome remodeling to the Ecad promoter, thus suppressing Ecad transcription [139]. On the contrary, reactivation of Ecad expression can result from deacetylation of its transcriptional repressor SNAI2 (SLUG) [140]. A comparative analysis of epigenetic events in breast and ovarian cancer related to tumorigenesis [141] identified genetic, microenvironmental, stromal, and epigenetic changes common between breast and ovarian cancer cells, as well as the clinical relevance of these changes. Some of the most striking commonalities included epigenetic alterations in H3K27me3, H3K9me2, H3K9me3, H4K20me3, and H3K4me suggesting shared features of pathogenesis in EOC and breast cancer and pointing out novel directions for managing EOC progression. Epigenetic profiling of ovarian cancer cells following TGF- $\beta$ treatment discovered significant hypermethylation changes in the loci associated with EMT and cellular movement amongst others [142]. Moreover, the authors showed that TGF- $\beta$ also stimulated expression and activity of DNMTs, while treatment with DNMT inhibitor SGI-110 abrogated TGF- $\beta$-mediated EMT [142]. Epigenetic silencing of secreted frizzled-related protein 5 (SFRP5), important in Wnt signaling regulation, activates the later and thus promotes EOC progression and drug resistance through TWIST-mediated EMT and AKT2 signaling [143]. IQGAP2 was found to be significantly hypermethylated in EOC [144] showing an inverse correlation between IQGAP2 DNA methylation and mRNA expression as IQGAP2 expression was downregulated in EOC. The subsequent survival analysis revealed that decreased IQGAP2 was associated with the low progression-free survival of EOC patients. Moreover, IQGAP2 was shown to suppress Wnt-induced $\beta$-catenin nuclear translocation and transcriptional activity, therefore inhibiting EMT, cell invasion and migration. Thus, IQGAP2 was identified as a novel EOC tumor suppressor via repression of invasion through Wnt/ $\beta$-catenin signaling and was suggested as a new potential therapeutic strategy for EOC treatment. Numerous DNA methylation aberrations have been recognized in EOC. The examples provided above and summarized in Table 1 highlight the potential clinical implications as novel biomarkers for EOC diagnosis and disease progression. More details on candidate genes for epigenetic therapy of EOC can be found in [145-147].

Table 1. Target and candidate genes with EMT-associated epigenetic modifications.

\begin{tabular}{|c|c|c|}
\hline Target or Candidate Gene & Epigenetic Modification & Reference \\
\hline \multirow[b]{3}{*}{ CDH1 (Ecad), silenced } & hypermethylation via $5^{\prime} \mathrm{CpG}$ island & [129-131] \\
\hline & $\begin{array}{l}\text { methylation via ZEB1 through recruitment of DNMT1 to } \\
\text { CDH1 promotor }\end{array}$ & [132] \\
\hline & $\begin{array}{l}\text { histone H3K27m3 demethylation at the SNAI1 promotor; } \\
\text { mono-, di- and trimethylation of histones H3K36m2, } \\
\text { H3K4m2, H3K9m3, H4K20m1, H3K9m1/2 by } \\
\text { methyltransferases MMSET, LSD1, Suv39H1, SET8 and G9a } \\
\text { at the TWIST, CDH1s and CDH2 promoters }\end{array}$ & {$[128,133-136]$} \\
\hline CDH1 (Ecad), reactivated & deacetylation of SNAI2 & [140] \\
\hline SFRP5, silenced & hypermethylation in EOC through Wnt signaling pathway & [143] \\
\hline IQGAP2, silenced & hypermethylated in EOC via Wnt/ $\beta$-catenin signaling & [144] \\
\hline $\begin{array}{l}\text { CDH1, ERBB3, FGFBP1, IGFBP4, IL1RN, MMP9, } \\
\text { SNAI3, SPP1, WNT11, WNT5B (downregulated) }\end{array}$ & TGF- $\beta$ induced methylation & [142] \\
\hline $\begin{array}{l}\text { BMP1, COL1A2, COL3A1, COL5A2, FOXC2, GSC, } \\
\text { KRT14, KRT7, MMP2, MMP3, RGS2, SNAI1, TCF4, } \\
\text { TFPI2, TGFB2, WNT5A, ZEB2 (upregulated) }\end{array}$ & TGF- $\beta$ induced methylation & [142] \\
\hline
\end{tabular}

\subsection{Posttranslational Modifications (PTMs)}

The most commonly present PTMs mediating EMT include phosphorylation and glycosylation. Phosphorylation of SNAI1 motifs by different protein kinases (such as GSK-3 $\beta$ and protein kinase 
D1) subsequently initiates its ubiquitination and degradation, thereby restoring expression of Ecad [148-150]. Inhibition of these protein kinases leads to Ecad repression and EMT. By contrast, glycosylation of SNAIL stabilizes it by preventing its phosphorylation and subsequent degradation, thus supporting EMT activation [151]. Another PTM, SUMOylation (binding of a small ubiquitin-like modifier, SUMO, to the target transcription factor) acts in a suppressive manner and is important for stabilizing and deactivating transcription factors engaged in EMT. In particular, in breast cancer the transcription factor Forkhead box protein M1 (FoxM1) is known to induce EMT via SNAI2 (SLUG) promoter stimulation [152], while in pancreatic cancer, FoxM1 upregulates ZEB1, ZEB2, SNAI2 and vimentin [153]. Yet another transcription factor Smad-interacting protein 1 (SIP1) acts as a downregulator of Ecad [154]. Impaired SUMOylation contributes to constant activation of these factors and, thus, enhances cadherin switching and EMT. One of the important promoters of EOC is the Hippo pathway signaling, which has been shown to affect several key signaling molecules via various types of PTMs $[155,156]$. In particular, the malfunction of critical Hippo signaling modules such as YAP/TAZ, MAT1/2 and LATS1/2 due to deregulated PTMs has been linked to different types of cancer including EOC. The current knowledge of PTMs with respect to the Hippo signaling pathway and possible therapeutic interventions targeting PTMs and Hippo signaling have been recently reviewed in [155]. Additional information on mediation of EMT at the post-translational level and an overview of various therapeutic approaches currently being investigated to undermine EMT can be found in [128].

\subsection{MicroRNAs}

Multiple microRNAs have been reported to serve as EMT promoters or inhibitors $[157,158]$. Members of the miR-205 and miR-200 family suppress EMT by binding the mRNAs encoding ZEB1 and ZEB2 [159,160]. Interestingly, both miR-205 and miR-200 family members negatively correlate with the expression of another EMT driver TWIST1, and are themselves transcriptionally silenced by TWIST1, which directly binds miR-205/miR-200 promoters and further intensifies EMT, complementing its well-known Ecad-suppressive role [161]. MiR-132/212 tandem miRNAs inhibit TGF- $\beta$-associated EMT by blocking the SOX4 gene in prostate cancer [162] and alleviate EMT and invasion of cervical cancer via SMAD2 downregulation [163]. Mir-132 directly silences ZEB2, thus attenuating EMT, invasion and metastasis in colorectal [164] and lung [165] cancers, and reduces EMT and migratory/invasive capacity of human non-small cell lung carcinoma (NSCLC) through the EMT-related TGF- $\beta 1 /$ Smad2 pathway [166]. MiR-150 triggers EMT and metastatic behavior in NSCLC in vitro and in vivo through downregulation of FOXO4 [167]. In contrast, in esophageal squamous cell carcinoma, miR-150 induces MET-like changes and blocks murine xenograft tumor growth by targeting ZEB1 [168]. MiR-9 stimulates EMT via immediate repression of Ecad-encoding mRNA [169]. In lung cancer-initiating cells, miR-145 downregulates stem-like properties and EMT via blocking Oct4 [170]; alternatively, in NSCLC, miR-145 and -203 are involved in TGF- $\beta$-related EMT inhibition through targeting SMAD3 [171]. Among other known pro-metastatic (pro-EMT) microRNAs are miR-27 [172,173], miR-29a [174-176], miR-103/107 [177,178], miR-221/222 [179-181] and miR-661 [182]; alternatively, miR-26a [183,184], miR-26a-5p [185,186], miR-30a [187-189], miR-30a-5p [190], miR-134 [191], miR-194 [192-194], miR-192 and -215 [194], and miR-204 [195-198] exhibit anti-EMT activity.

A large number of microRNAs are implicated in ovarian carcinogenesis, tumor progression and in EMT in particular. A comparative study investigating expression of the miR-200 family, ZEB1 and ZEB2 transcriptional repressors in normal OSE vs. 15 EOC cell lines and 70 ovarian carcinoma tissues revealed that malignant transformation is associated with acquisition of more epithelial traits, such as upregulation of miR-200 family members and attenuation of ZEB1/2 [199], supporting the occurrence of MET, not EMT, during early stages of ovarian cancer progression. The miR-196 family, located in the Hox gene cluster, regulates (usually by inhibition) the HOX genes, in particular HOXA7, which is responsible for controlling the differentiation status in ovarian epithelium. HOXA7 overexpression is associated with the initiation of MET in ovarian epithelium and generation of low-grade Ecad-positive ovarian tumors [200]. Mir-9 levels are often elevated in ovarian cancer tissues in comparison with 
normal control tissues and are associated with EMT via targeting of Ecad by miR-9 and consequent enhancement of Ncad and vimentin expression [201]. Transcriptional regulator Snail is the direct target of miR-30d, which inhibits TGF- $\beta 1$ - induced EMT in ovarian cancer cells [202]. MiR-424 can suppress cell invasion and EMT via downregulation of DCLK1 in ovarian clear cell carcinoma, a subtype of EOC, associated with drug resistance and low survival rate [203]. MiR-382 serves as an ovarian cancer suppressor due to regulating EMT by targeting ROR1 and negatively impacting EOC cell migration/invasion [204]. A recently discovered miR-506 is one of the crucial down-regulators of EMT and metastasis in EOC through both immediate repression of transcriptional repressor SNAI2 (thus, restoring Ecad expression) and negative regulation of Ncad and vimentin, and is associated with a better survival prognosis [205]. Another EOC EMT- and metastasis-suppressor is miR-7, which acts through EGFR and AKT/ERK1/2 pathway inactivation [206]. More microRNA aberrations observed in EOC are concisely summarized in a review [207].

The concept of microRNA detection in physiological fluids in order to establish new predictive and diagnostic markers is gaining in popularity. A recent analysis of serum-circulating exosomal microRNAs revealed a broad increase in miR-373 and miR-200a in patients with ovarian serous adenocarcinoma across all stages (I-IV), while miR-200b and miR200c were more significantly elevated in later stages (III-IV) and correlated with worse survival outcome, suggesting that these microRNAs may differentially modulate EMT/MET shifts during certain EOC progression steps [208]. Another study [209] evaluating 2222 total microRNAs from ovarian cancer patient serum samples identified the most stably and markedly downregulated microRNAs as miR-132, miR-26a, and miR-145 (which are known to act as EMT-repressors in other tissue types, as discussed above), as well as let-7b, a microRNA that was recently shown to play multiple anti-tumor roles, including anti-EMT (through attenuation of $\mathrm{p}$-AKT, Twist and $\beta$-catenin) and pro-apoptosis in malignant mesothelioma cells [210]. A 1,170 patient-based meta-analysis of global transcriptome data delineated let-7b as a stratification factor for molecular and clinical classification, and a predictor of poor survival outcome in high grade serous ovarian carcinoma [211]. Urinary miR-30a-5p was recently reported to be exclusively elevated in ovarian serous adenocarcinoma patients, both at early and metastatic stages of the malignancy and derived specifically from EOC tissue [212]. In contrast, elevation of miR-30a-5p in patients with benign gynecological diseases, gastrointestinal tumors and in the healthy control group was not detected. Moreover, targeted inhibition of miR-30a-5p considerably mitigated ovarian cancer pro-metastatic behavior in vitro [212]. In addition to EMT mediation, the majority of involved microRNAs play multiple roles in ovarian cancer initiation, progression, metastasis, stemness, microenvironmental and chemotherapeutic responses. In a paired analysis, miR-21, miR-150, and miR-146a were shown to be significantly overexpressed in EOC omental metastatic lesions in comparison with their matching primary tumor samples from the same patients [213]; moreover, miR-150 and -146a were also shown to regulate the size of EOC multicellular spheroids, cell survival and chemoresistance to cisplatin [213]. Amongst others, miR-181a is shown to facilitate TGF- $\beta$-mediated EMT through downregulation of SMAD7, contributing to cell survival, metastasis-associated behavior and chemoresistance in high grade serous ovarian carcinomas [214]. Further elucidation of signaling pathways and molecular targets of clinically dysregulated microRNAs in EOC is of profound importance, warranting discovery of new predictive markers, diagnostic tools and targeted therapeutic strategies. A comprehensive analysis (2014) based on evaluation of almost 100 research publications provides a structured summary of potentially relevant prognostic, diagnostic and therapeutic microRNAs for ovarian cancer [215]. Yet, another thorough review summarizes the most recent advances in clinical applications (including current clinical trials) of microRNAs for ovarian cancer precision medicine [216].

\subsection{Long Noncoding RNAs (lncRNAs)}

LncRNAs are a large class of RNAs transcripts having a length of more than 200 nucleotides which do not encode proteins. LncRNAs have gained widespread attention in recent years due to 
the vast implications in cancer biology, contributing to essential cellular functions including invasion, proliferation, differentiation, apoptosis, cell cycle progression and metastasis [217-220]. Although emerging as a new class of regulators in cancer progression, the role of lncRNAs in EOC and the relationship to EMT/MET in EOC has just begun to be explored.

A comprehensive study using clinical data from 544 ovarian cancer patients from The Cancer Genome Atlas (TCGA) examined lncRNA expression profiles [221], identifying an eight-lncRNA signature (RP4-799P18.3; PTPRD-AS1; RP11-57P19.1; RP11-307C12.11; RP11-254I22.1; RP11-80H5.7; RP1-223E5.4; GACAT3) permitting classification of patients into two groups characterized as high-risk + poor outcome and low-risk + significantly improved outcome. In particular, a superior prognosis performance in BRCA1/2-mutated and BRCA1/2 wild-type tumors was achieved by associating predictions with BRCA1 and BRCA2 mutations. It was shown that the eight-lncRNA signature may serve as a metric to predict chemotherapy response in patients and identify resistance to platinum treatment suggesting other more efficient therapies. These findings support that lncRNAs can be used as diagnostic or prognostic biomarkers in patients with EOC.

Upregulation of the IncRNA ZFAS1 was recently reported in EOC and negatively correlated with overall survival of patients with ovarian carcinomas [218]. It was established that overexpression of ZFAS1 increased proliferation, migration and chemoresistance in EOC cells. miR-150-5p was identified as a potential target of ZFAS1, suppressing the transcription factor Sp1. Meanwhile, inhibition of miR-150-5p partially restored proliferation and migration resulting from depletion of ZFAS1. Thus, the ZFAS1/miR-150-5p/Sp1 pathway was shown to be critical in inducing migration, differentiation and chemoresistance in EOC.

In another study [222], IncRNA HOX transcript antisense RNA (HOTAIR) expression in EOC tissues was evaluated and its correlation with clinico-pathological factors was established. Suppression of HOTAIR in three highly metastatic EOC cell lines (SKOV3.ip1, HO8910-PM, and HEY-A8) significantly reduced cell migration and invasion. Furthermore, the pro-metastatic effects were partially mediated by MMPs along with EMT-related genes. Specifically, siRNA-mediated silencing of HOTAIR increased expression of Ecad and decreased expression of vimentin and Snail.

TGF- $\beta$ signaling has been shown to serve as a major promoting factor of EMT, facilitating EOC and breast cancer metastasis. Although the relationship between lncRNA and TGF- $\beta$ in EOC is not known, the lncRNA profile in mouse mammary epithelial NMuMG cells upon TGF- $\beta$-mediated induction of EMT has been reported [223], identifying a subset of lncRNAs dysregulated upon TGF- $\beta$ induced EMT with lncRNA-HIT mediating this process by targeting Ecad. These findings reveal a pivotal role that lncRNAs may play in EMT in breast cancer progression and warrant further studies examining relation between IncRNA profile and TGF- $\beta$-induced EMT in EOC. Collectively, these studies suggest a direct or indirect relationship between lncRNA and regulation of EOC invasion and metastasis, as well as new mechanisms involved in EOC EMT, which can potentially result in novel markers and therapeutic targets for epithelial ovarian cancer.

\subsection{Biomechanical Forces}

The unique transcoelomic route of ovarian cancer metastasis with excessive dissemination within the abdominal cavity leads to obstruction of lymphatic tissues, enriched in peritoneal walls, and early malfunction of the peritoneal lymphatic drainage system [224-226]. Excessive neovascularization of the primary tumor and peritoneal lining [227-231], secretion of factors increasing vascular permeability [232-236] and as a consequence, high protein concentration [237], motivate intraperitoneal transudate aspiration. A disrupted balance between fluid production and fluid clearance generates large volumes of ascites, followed by a dramatic increase in intra-peritoneal pressure (IPP) [238] which subsequently alters intraperitoneal mechanobiology. Meanwhile, biomechanical cues, driven by fluid build-up, ascitic currents, stretching of the peritoneal tissues and organ dislocation currently remain relatively unexplored. One published study has shown that laminar fluid flow drives a more aggressive phenotype in 3-dimensional ovarian micro-nodules through induction of EMT, partially 
via post-translational upregulation of EGFR, as well as significant downregulation of Ecad and CDC2 expression [239]. These results are in conformity with a study reporting triggering of EMT in laryngeal squamous cell carcinoma by fluid shear stress through integrin-ILK/PI3K-AKT-Snail signaling pathways [240]. Exposure to shear stress caused repression of Ecad with a simultaneous increase in Ncad expression and translocation of $\beta$-catenin into the nucleus, alteration of cell morphology to an elongated shape with invadopodia enrichment, and stimulated cell migration; furthermore, these alterations were reversible upon removal of mechanical stress [240]. Conversely, another study addressing the effects of fluid sheer stress on EMT and cancer stem cell (CSC) properties in breast cancer cells documented CSC-like signature promotion with no changes in EMT markers [241]. Peritoneal fluid dwell was shown to drive EMT and hyperplasia of mesothelial cells in an in vitro reconstructed peritoneal cavity model [242]. A transcriptome-wide analysis of microRNA profiles in breast cancer cells and cancer-associated fibroblasts in response to compressive strain revealed alterations in expression levels of microRNAs associated with EMT, migration, invasion, angiogenesis and apoptosis [243]. In 3D breast cancer aggregates, elevated interstitial fluid pressure guided EMT shifting and collective cell invasion through Snail, vimentin and Ecad gene expression alterations [244]. In normal and hypertrophic scar fibroblasts, mechanical compression altered expression of TGF- $\beta$ signaling target genes SMAD2 and SMAD3 and further upregulated expression of MMP-2 and MMP-9 [245]. Potential alterations in ovarian cancer progression mediated by ascites-induced changes in peritoneal mechanobiology have yet to be uncovered. One recent study has revealed significant enhancement of SNAI1 gene expression in epithelial-type EOC cells and MCAs upon continuous patho-physiologically relevant compression $(\sim 22 \mathrm{mmHg})$, applied to mimic ascites-driven elevations in IPP as observed in the clinic [246]. Additionally, elevated mRNA and protein expression levels of Ecad and Ncad in EOC epithelial- and mesenchymal-type MCAs, respectively, heightened the distinction between these morphological phenotypes [246].

\section{Controversy on EMT and Chemoresistance in EOC}

Progress made in elucidation of EMT as a continuously evolving process rather than two distinct end stages has heightened controversies related to the divergent behavior of epithelial and mesenchymal cancer cells during metastatic spreading and their response to therapeutic interventions. The link between induction of EMT and the development of drug resistance has been confirmed for multiple cancer types and has gained the attention of researchers worldwide to identify new therapeutic targets that abrogate EMT and re-sensitize cancers to chemotherapeutic drugs. A recent report elegantly illustrates the mechanisms underlying EMT-dependent acquisition of resistance to diverse therapeutic agents observed in different types of cancers, and stratifies approaches for targeting the EMT program as a part of cancer treatment, focusing on prevention of EMT induction, selective targeting of cells that have undergone the EMT shift, and launching the reverse MET program in mesenchymal cancer cells [12].

In ovarian cancer, however, the association between EMT and drug resistance remains disputable, as numerous research data provide contradictory conclusions. For example, activation of Notch3 signaling in ovarian cancer OvCa429 cells (epithelial-type) launched EMT and attenuated carboplatin-induced apoptosis in these cells through inhibited ERK phosphorylation [247]. Similarly, promotion of EMT by hematopoietic PBX interacting protein [248], NANOG [249,250], TWIST1 [251,252], SNAI1 [253] FOXM1 [254] accompanied acquisition of ovarian cancer cell resistance to conventional therapeutic agents, such as cisplatin, carboplatin or paclitaxel. Contrary to these are data from a study that exploited sensitivity to cisplatin among 46 ovarian cancer cell lines and established a higher level of drug resistance in the cells with epithelial status [57]. Subsequent pathway analyses discovered activation of the NF- $\mathrm{B}$ pathway by administered cisplatin exclusively in epithelial cells, resulting in defective apoptosis and cisplatin resistance [57]. Another study showed downregulation of miRNA-200 family members (microRNAs that act as supressors of EMT) in paclitaxel- and carboplatin-resistant ovarian cancer cells with a strong mesenchymal phenotype, 
but surprisingly, overexpression of miR-200c/miR-141 in these cells and partial restoration of epithelial traits led to a $6-8 \mathrm{x}$ higher resistance to carboplatin while showing no change in response to paclitaxel. Yet another study characterized tumor cell clusters from ovarian cancer patient ascites and identified that cells/clusters with mesenchymal markers were predominantly derived from chemo-naïve patients, whereas cellular components of the epithelial phenotype were found in ascites of patients with recurrent disease and chemoresistance [56]. Further, comparison of ascites-driven single cells of epithelial and mesenchymal morphology (confirmed by respective marker expression) depicted a significantly higher level of resistance to cisplatin in epithelial-type cells relative to mesenchymal-type cells [56].

Clearly, additional research is needed to fully understand the relationship between EMT/MET and chemoresistance in ovarian cancer, as it will allow recruitment of EMT regulators to combat EOCs significant challenges-multidrug resistance and metastatic aggressiveness. Given the distinct mechanism of ovarian cancer metastatic dissemination and the unique aspects of epithelial vs. mesenchymal EOC cells, nontrivial EMT-targeting therapeutic approaches might be required. In particular, current scientific knowledge highlights ovarian cancer epithelial-state cells as more chemo- and radiation resistant (as outlined in Sections 3 and 5 of this commentary), raising a speculation that new therapeutic interventions may actually lie in EMT promotion for re-sensitization of EOC cells to therapeutic agents-a strategy opposite to that suggested for other cancer types [12]. However, pre-clinical data including those of our group (see Section 3 of the current review) indicate that acquisition of the mesenchymal phenotype in EOC is particularly associated with aggressive metastatic invasion. In this case, as our latest report concludes [45], targeting Ncad on the surface of mesenchymal-type EOC cells with Ncad-blocking peptides, such as the HAV-motif harboring drug ADH-1 (Exherin) or monoclonal antibodies may represent a promising anti-metastatic strategy. Future studies designed to resolve the EOC EMT/chemoresistance controversies and target the unique characteristics of EOC cells are warranted.

\section{Computational Modeling Approaches to Understanding EMT/MET in EOC}

Computational systems biology models have become an indispensable tool in analyzing highly empirical cancer progression data and can greatly contribute to elucidating the underlying principles of EMT/MET in EOC. Regulatory networks underlying these transitions in EOC as well as other cancer types involve multiple signaling pathways including TGF- $\beta$, EGF, HGF, FGF, NF-kB, Wnt, Notch, Hedgehog, JAK/STAT, Hippo [255], and hypoxia [256]. In addition, the mechanical properties of the extracellular matrix (ECM) such as density [257] and stiffness [258] also play role in EMT/MET. These signals trigger activation of EMT-inducing transcription factors involving ZEB1/2, SNAIL1/2, TWIST1, and Goosecoid, thereby repressing epithelial genes including Ecad. As mentioned previously, microRNA-mediated control of translation, splicing of mRNAs and epigenetic modifiers can also regulate EMT/MET $[259,260]$. Various feedback loops discussed can alter plasticity of the cell and enable the existence of intermediate phenotypes. Understanding how these multiple factors govern epithelial-hybrid-mesenchymal states stimulated the development of mathematical models to study the underlying mechanisms, as well as the dynamics, stability and reversibility of EMT. Although EOC-specific EMT/MET computational models are not well-represented in the literature, the existence of similar EMT/MET signaling pathways in different cancer types suggests logical extension of existent models to EOC.

\subsection{Regulatory Networks-Based Models of EMT/MET}

To delineate the emergent dynamics of EMT/MET regulatory networks, low- and high-dimensional kinetic models have been developed [261-263]. 


\subsubsection{Low-Dimensional Models}

The two major low-dimensional models focus on describing individual reactions between a set of micro-RNAs families and comprise miR-34, miR-200 and EMT-TF ZEB and SNAIL players. As was reported recently $[261,262]$ these networks allow for co-existence of epithelial (E) and mesenchymal (M) phenotypes along with a hybrid epithelial-mesenchymal (E-M) phenotype, observed experimentally in many studies revealing subpopulations of E, M, and E-M cells in various cell lines [80]. The fact that E-M clustering can result in a significantly larger amount of EOC secondary tumors as compared to pure E or M phenotype [81], therefore impacting metastatic success, makes the small-scale model a critical component in predicting the outcome of $\mathrm{E}, \mathrm{M}$ and $\mathrm{E}-\mathrm{M}$ cell interactions. The modeling approach developed by Lu et al. [261] uses a theoretical framework to account for microRNA- and transcription factor-mediated interactions. The model suggests that miR-200/ZEB feedback loop works as a switch allowing for three stable states and that hybrid E-M cells correspond to intermediate miR-200 and ZEB levels. In contrast, Tian et al. [262] proposed a simplified model applying mathematical forms to consider translational and transcriptional interactions. In their work, it is hypothesized that both miR-200/ZEB and miR-34/SNAIL act as bi-stable switches and the hybrid E-M phenotype is caused by low ZEB and high SNAIL levels.

The impact of other transcription factors modulating EMT/MET in the low-dimensional approach was also considered. In particular, GRHL2 and OVOL2 were shown to act as 'phenotypic stability factors' (PSFs) allowing for the existence of a hybrid E-M phenotype at a wider range of model parameters [72,264]. The regulatory network in the later study [264] coupled OVOL with miR-34/SNAIL and miR-200/ZEB circuits. The core of the EMT regulatory network comprised of self-inhibitory OVOL which formed a mutually inhibitory loop with ZEB and indirectly inhibited miR-200 via STAT3. TGF- $\beta$ activated SNAIL, and BMP7/Smad4 pathway and C/EBP- $\beta$ activated OVOL, whereas Wg signaling (Armadillo/dTCF) inhibited OVOL.

In application to ovarian cancer modeling, suppression of GRHL2 was recently shown to inhibit proliferation, invasion, and migration of ovarian cancer cells [265], emphasizing the importance of incorporating this factor into a low-dimensional EOC EMT/MET model. Additionally, extracellular communications such as those mediated by JAG1 were shown to be able to perform the role of PSF via Notch-Jagged signaling [266]. Furthermore, to quantify global stability of the hybrid phenotype in EOC EMT and transition dynamics among different phenotypes, the landscape and kinetic paths approach needs to be used to aid in understanding the mechanisms of EMT processes, and unveil possible roles for the intermediate E-M states [267,268].

\subsubsection{High-Dimensional Models}

In contrast to low-dimensional kinetic models, high-dimensional, large-scale regulatory network models have been developed based on Boolean formalism focusing on the logical topology of the networks. Following this approach an EOC EMT network of multiple nodes and edges can be constructed to simulate the dynamics of transcription factors and microRNAs. This methodology has been successfully used in a study [263] that considered a network of 70 nodes and 135 edges to follow the dynamics of TGF- $\beta$-driven EMT in hepatocellular carcinoma. The nodes of the network represented molecular entities (proteins, small molecules, mRNAs) while the edges depicted activating and inhibitory relationships between nodes. Upstream signals (SHH, Wnt, HGF, PDGF, IGF1, EGF, FGR, Jagged, TGF- $\beta$, DELTA, CHD1L, Goosecoid, Hypoxia) regulated transcriptional regulators (SNAI1, SNAI2, FOXC2, TWIST1, ZEB1, ZEB2) through signal transduction pathways, which all converged on the regulation of E-cadherin state, defining the EMT output of the network. A related study [269] simulated multiple signaling pathways, microRNAs and transcription factors to derive mutations and functional changes in network nodes that result in altered metastatic behavior.

One of the advantages of using the logical network formalism is that it provides a larger set of steady states compared to kinetic-mechanism based models due to higher dimensionality of the system considered. The large scale network approach allows for better characterization of EMT by providing 
a more detailed profile of transient hybrid E-M states. Yet, Boolean modeling framework considers each node to take discrete 'on' and 'off' states which makes it difficult to simulate transitions involving continuous-like switches such as the transcription factor ZEB.

Overall, both low- and high-dimensional models complement each other in identifying regulatory network-based mechanisms of EMT/MET and can perform as an efficient computational tool to recognize stability factors allowing for existence of E-M hybrid phenotypes in EOC.

\subsection{Omics-Based Models of EMT}

Typical omics-level models of EMT use gene expression data which is then analyzed using statistical methods for identifying transition patterns and characterization of trajectories between phenotypes. By applying methods of chemical reaction dynamics, changes in transcriptional profile in the course of EMT were studied [270]. It was shown that a stable low-energy intermediate state exists in the landscape of the free energy changes during TGF- $\beta 1$-induced EMT for the lung cancer cells coinciding with metabolic shifts. In another study [271], integration of time-course EMT transcriptomic data with public cistromic data allowed investigators to identify three synergistic master transcription factors, namely ETS2, HNF4A and JUNB, that regulated the transition between partial EMT states. Removal of these factors abrogated TGF- $\beta$-induced EMT. Likewise, application of these models to TGF- $\beta$-induced EMT in EOC can identify transcription factors responsible for the hybrid E-M phenotype which can be further examined experimentally.

Another useful model approach which was applied to EMT in EOC along with other cancer types was suggested in [272], enabling quantification of the EMT spectrum in the course of cancer progression. In this model, transcriptomics data are used to identify a generic EMT signature involving common molecular signatures of EMT across tumors and cell lines of different origins comprising bladder, breast, colorectal, gastric, lung and ovarian cancers. For a given sample the EMT score is then calculated using a two-sample Kolmogorov-Smirnov test in the range from -1 to +1 with the positive scores indicating mesenchymal, and negative scores corresponding to epithelial phenotype. Interestingly, the generic EMT scores of EOC tumors were slightly negative (around -0.1) pointing out a slight shift towards epithelial phenotype, whereas ovarian cancer cell lines revealed more mesenchymal phenotype with positive scores $(+0.25)$. The results of the model suggest that EMT status does not necessarily translate to chemotherapeutic resistance and correlate with poorer survival.

\subsection{Multiscale Models of EMT}

The goal of multiscale models is to link the intracellular dynamics of EMT signaling pathways to the adhesion molecules on the cell surface and changes in tumor cell invasion through the extracellular matrix. A multiscale individual-based lattice-free model accounting for the intracellular dynamics of the Ecad- $\beta$-catenin interaction and external mechanical forces was developed [273]. Each cell was modeled as an isotropic elastic body permitting migration and division calibrated using cell-kinetic, biophysical and cell-biological experimental data. The results indicate that some of migratory features of EMT can be reproduced in the model when the extracellular gradient of chemoattractant is induced and the system of proteasomes responsible for degrading $\beta$-catenin is downregulated.

Monte Carlo-based model simulations of EMT were presented [274] with focus on the formation of cardiac cushions during embryonic development of the heart. Cell rearrangements are provided in terms of Steinberg's differential adhesion hypothesis suggesting type-dependent adhesion along with motility levels sufficient to result in tissue conformations with the largest number of strong bonds. The model couples differential adhesion, EMT, cell proliferation and matrix production by mesenchymal cells, and predicts that increases in cell-ECM interactions might be more important in promoting EMT than decreases in cell-cell adhesion.

Stochastic and deterministic models describing tumor growth based on the cancer stem cell hypothesis in application to EMT were given [275], wherein the possibilities of using quantitative approaches for identification of an increase in stem cell activity following promotion of EMT were 
discussed. The cancer stem cell hypothesis implies that not all tumor cells are equal in terms of their roles in treatment resistance, therefore suggesting possible therapeutic targets in EOC. If EMT can lead to formation of CSCs from non-stem cancer cells, then EMT must be targeted along with CSCs, as non-stem population may recover the CSC pool.

Various computational and statistical models of EMT can contribute significantly by providing a quantitative assessment of EMT dynamics that incorporate EOC genetic and biophysical parameters, which can then be tested experimentally to yield further insight into mechanisms driving EMT.

\section{Conclusions}

Successful metastatic dissemination of EOC in the complex peritoneal microenvironment necessitates dynamic and reversible changes in cell-cell interaction as cancer progresses from the primary tumor to free-floating MCAs and matrix-anchored metastases. This unique metastatic niche provides a diversity of biochemical and biomechanical cues that, together with the inherent phenotypic plasticity of EOC cells, promotes EMT and MET at various stages in metastatic progression. Additional research designed to mechanistically integrate key drivers of the EMT/MET program will undoubtedly identify a wealth of potential therapeutic targets to inhibit successful metastatic spread and thereby improve survival of women with EOC.

Acknowledgments: This work was supported in part by Research Grants RO1CA109545 (M.S.S.) and RO1CA086984 (M.S.S.) from the National Institutes of Health/National Cancer Institute; the Leo and Anne Albert Charitable Trust (M.S.S.); the Research Like a Champion grant (Y.K.); the Walther Cancer Foundation Seeding Research in Cancer grant (O.K.); and the Scientist Development Grant SDG33680177 (O.K.) from American Heart Association.

Conflicts of Interest: The authors declare no conflict of interest.

\section{References}

1. Chaffer, C.L.; Weinberg, R.A. A Perspective on Cancer Cell Metastasis. Science 2011, 331, $1559-1564$. [CrossRef] [PubMed]

2. Hanahan, D.; Weinberg, R.A. Hallmarks of Cancer: The Next Generation. Cell 2011, 144, 646-674. [CrossRef] [PubMed]

3. Weinberg, R. The Biology of Cancer; Garland Science: New York, NY, USA, 2013.

4. Valastyan, S.; Weinberg, R.A. Tumor Metastasis: Molecular Insights and Evolving Paradigms. Cell 2011, 147, 275-292. [CrossRef] [PubMed]

5. Fidler, I.J. The Pathogenesis of Cancer Metastasis: The 'Seed and Soil' Hypothesis Revisited. Nat. Rev. Cancer 2003, 3, 453-458. [CrossRef] [PubMed]

6. Yoshida-Noro, C.; Suzuki, N.; Takeichi, M. Molecular Nature of the Calcium-Dependent Cell-Cell Adhesion System in Mouse Teratocarcinoma and Embryonic Cells Studied with a Monoclonal Antibody. Dev. Biol. 1984, 101, 19-27. [CrossRef]

7. Takeichi, M. The Cadherins: Cell-Cell Adhesion Molecules Controlling Animal Morphogenesis. Development 1988, 102, 639-655. [PubMed]

8. Li, G.; Satyamoorthy, K.; Herlyn, M. N-Cadherin-Mediated Intercellular Interactions Promote Survival and Migration of Melanoma Cells. Cancer Res. 2001, 61, 3819-3825. [PubMed]

9. Mariotti, A.; Perotti, A.; Sessa, C.; Rüegg, C. N-Cadherin as a Therapeutic Target in Cancer. Expert Opin. Investig. Drugs 2007, 16, 451-465. [CrossRef] [PubMed]

10. Gerhardt, H.; Wolburg, H.; Redies, C. N-cadherin Mediates Pericytic-endothelial Interaction during Brain Angiogenesis in the Chicken. Dev. Dyn. 2000, 218, 472-479. [CrossRef]

11. Blaschuk, O.W. N-Cadherin Antagonists as Oncology Therapeutics. Philos. Trans. R. Soc. Lond. B. Biol. Sci. 2015, 370, 20140039. [CrossRef] [PubMed]

12. Shibue, T.; Weinberg, R.A. EMT, CSCs, and Drug Resistance: The Mechanistic Link and Clinical Implications. Nat. Rev. Clin. Oncol. 2017. [CrossRef] [PubMed]

13. American Cancer Society. Cancer Facts E Figures 2017; American Cancer Society: Atlanta, GA, USA, 2017. 
14. Siegel, R.L.; Miller, K.D.; Jemal, A. Cancer Statistics, 2016. CA Cancer J. Clin. 2016, 66, 7-30. [CrossRef] [PubMed]

15. Howlader, N.; Noone, A.M.; Krapcho, M.; Garshell, J.; Miller, D.; Altekruse, S.F.; Kosary, C.L.; Yu, M.; Ruhl, J.; Tatalovich, Z.; et al. SEER Cancer Statistics Review, 1975-2008; National Cancer Institute: Bethesda, MD, USA, 2011.

16. Marcus, C.S.; Maxwell, G.L.; Darcy, K.M.; Hamilton, C.A.; McGuire, W.P. Current Approaches and Challenges in Managing and Monitoring Treatment Response in Ovarian Cancer. J. Cancer 2014, 5, 25. [CrossRef] [PubMed]

17. Hudson, L.G.; Zeineldin, R.; Stack, M.S. Phenotypic Plasticity of Neoplastic Ovarian Epithelium: Unique Cadherin Profiles in Tumor Progression. Clin. Exp. Metastasis 2008, 25, 643-655. [CrossRef] [PubMed]

18. Lengyel, E. Ovarian Cancer Development and Metastasis. Am. J. Pathol. 2010, 177, 1053-1064. [CrossRef] [PubMed]

19. Shield, K.; Ackland, M.L.; Ahmed, N.; Rice, G.E. Multicellular Spheroids in Ovarian Cancer Metastases: Biology and Pathology. Gynecol. Oncol. 2009, 113, 143-148. [CrossRef] [PubMed]

20. Feki, A.; Berardi, P.; Bellingan, G.; Major, A.; Krause, K.; Petignat, P.; Zehra, R.; Pervaiz, S.; Irminger-Finger, I. Dissemination of Intraperitoneal Ovarian Cancer: Discussion of Mechanisms and Demonstration of Lymphatic Spreading in Ovarian Cancer Model. Crit. Rev. Oncol. 2009, 72, 1-9. [CrossRef] [PubMed]

21. Pradeep, S.; Kim, S.W.; Wu, S.Y.; Nishimura, M.; Chaluvally-Raghavan, P.; Miyake, T.; Pecot, C.V.; Kim, S.; Choi, H.J.; Bischoff, F.Z. Hematogenous Metastasis of Ovarian Cancer: Rethinking Mode of Spread. Cancer Cell 2014, 26, 77-91. [CrossRef] [PubMed]

22. Coffman, L.G.; Burgos-Ojeda, D.; Wu, R.; Cho, K.; Bai, S.; Buckanovich, R.J. New Models of Hematogenous Ovarian Cancer Metastasis Demonstrate Preferential Spread to the Ovary and a Requirement for the Ovary for Abdominal Dissemination. Trans. Res. 2016, 175, 92-102. [CrossRef] [PubMed]

23. Auersperg, N.; Wong, A.S.T.; Choi, K.; Kang, S.K.; Leung, P.C.K. Ovarian Surface Epithelium: Biology, Endocrinology, and Pathology. Endocr. Rev. 2001, 22, 255-288. [CrossRef] [PubMed]

24. Auersperg, N. The Origin of Ovarian Carcinomas: A Unifying Hypothesis. Int. J. Gynecol. Pathol. 2011, 30, 12-21. [CrossRef] [PubMed]

25. Gillett, W.R.; Mitchell, A.; Hurst, P.R. A Scanning Electron Microscopic Study of the Human Ovarian Surface Epithelium: Characterization of Two Cell Types. Hum. Reprod. 1991, 6, 645-650. [CrossRef] [PubMed]

26. Auersperg, N. The Origin of Ovarian Cancers-Hypotheses and Controversies. Front. Biosci. 2013, 5, 709-719. [CrossRef]

27. Jarboe, E.; Folkins, A.; Nucci, M.R.; Kindelberger, D.; Drapkin, R.; Miron, A.; Lee, Y.; Crum, C.P. Serous Carcinogenesis in the Fallopian Tube: A Descriptive Classification. Int. J. Gynecol. Pathol. 2008, 27, 1-9. [CrossRef] [PubMed]

28. Carlson, J.W.; Miron, A.; Jarboe, E.A.; Parast, M.M.; Hirsch, M.S.; Lee, Y.; Muto, M.G.; Kindelberger, D.; Crum, C.P. Serous Tubal Intraepithelial Carcinoma: Its Potential Role in Primary Peritoneal Serous Carcinoma and Serous Cancer Prevention. J. Clin. Oncol. 2008, 26, 4160-4165. [CrossRef] [PubMed]

29. Kindelberger, D.W.; Lee, Y.; Miron, A.; Hirsch, M.S.; Feltmate, C.; Medeiros, F.; Callahan, M.J.; Garner, E.O.; Gordon, R.W.; Birch, C.; et al. Intraepithelial Carcinoma of the Fimbria and Pelvic Serous Carcinoma: Evidence for a Causal Relationship. Am. J. Surg. Pathol. 2007, 31, 161-169. [CrossRef] [PubMed]

30. Przybycin, C.G.; Kurman, R.J.; Ronnett, B.M.; Shih, I.; Vang, R. Are all Pelvic (Nonuterine) Serous Carcinomas of Tubal Origin? Am. J. Surg. Pathol. 2010, 34, 1407-1416. [CrossRef] [PubMed]

31. Roh, M.H.; Kindelberger, D.; Crum, C.P. Serous Tubal Intraepithelial Carcinoma and the Dominant Ovarian Mass: Clues to Serous Tumor Origin? Am. J. Surg. Pathol. 2009, 33, 376-383. [CrossRef] [PubMed]

32. Salvador, S.; Rempel, A.; Soslow, R.A.; Gilks, B.; Huntsman, D.; Miller, D. Chromosomal Instability in Fallopian Tube Precursor Lesions of Serous Carcinoma and Frequent Monoclonality of Synchronous Ovarian and Fallopian Tube Mucosal Serous Carcinoma. Gynecol. Oncol. 2008, 110, 408-417. [CrossRef] [PubMed]

33. Vang, R.; Shih, I.; Kurman, R.J. Fallopian Tube Precursors of Ovarian Low-and High-grade Serous Neoplasms. Histopathology 2013, 62, 44-58. [CrossRef] [PubMed]

34. Chene, G.; Dauplat, J.; Radosevic-Robin, N.; Cayre, A.; Penault-Llorca, F. Tu-be Or Not Tu-be: That is the Question ... about Serous Ovarian Carcinogenesis. Crit. Rev. Oncol. 2013, 88, 134-143. [CrossRef] [PubMed] 
35. Bapat, S.A.; Mali, A.M.; Koppikar, C.B.; Kurrey, N.K. Stem and Progenitor-Like Cells Contribute to the Aggressive Behavior of Human Epithelial Ovarian Cancer. Cancer Res. 2005, 65, 3025-3029. [CrossRef] [PubMed]

36. Bowen, N.J.; Walker, L.D.; Matyunina, L.V.; Logani, S.; Totten, K.A.; Benigno, B.B.; McDonald, J.F. Gene Expression Profiling Supports the Hypothesis that Human Ovarian Surface Epithelia are Multipotent and Capable of Serving as Ovarian Cancer Initiating Cells. BMC Med. Genom. 2009, 2, 71. [CrossRef] [PubMed]

37. Szotek, P.P.; Pieretti-Vanmarcke, R.; Masiakos, P.T.; Dinulescu, D.M.; Connolly, D.; Foster, R.; Dombkowski, D.; Preffer, F.; Maclaughlin, D.T.; Donahoe, P.K. Ovarian Cancer Side Population Defines Cells with Stem Cell-Like Characteristics and Mullerian Inhibiting Substance Responsiveness. Proc. Natl. Acad. Sci. USA 2006, 103, 11154-11159. [CrossRef] [PubMed]

38. Flesken-Nikitin, A.; Hwang, C.; Cheng, C.; Michurina, T.V.; Enikolopov, G.; Nikitin, A.Y. Ovarian Surface Epithelium at the Junction Area Contains a Cancer-Prone Stem Cell Niche. Nature 2013, 495, 241-245. [CrossRef] [PubMed]

39. Seidman, J.D.; Yemelyanova, A.; Zaino, R.J.; Kurman, R.J. The Fallopian Tube-Peritoneal Junction: A Potential Site of Carcinogenesis. Int. J. Gynecol. Pathol. 2011, 30, 4-11. [CrossRef] [PubMed]

40. Paik, D.Y.; Janzen, D.M.; Schafenacker, A.M.; Velasco, V.S.; Shung, M.S.; Cheng, D.; Huang, J.; Witte, O.N.; Memarzadeh, S. Stem-Like Epithelial Cells are Concentrated in the Distal End of the Fallopian Tube: A Site for Injury and Serous Cancer Initiation. Stem Cells 2012, 30, 2487-2497. [CrossRef] [PubMed]

41. Ng, A.; Barker, N. Ovary and Fimbrial Stem Cells: Biology, Niche and Cancer Origins. Nat. Rev. Mol. Cell Boil. 2015, 16, 625-638. [CrossRef] [PubMed]

42. Klymenko, Y.; Stack, M.S. Abstract B6: Cadherin Switching, Multicellular Aggregate Dynamics and Metastatic Success. Clin. Cancer Res. 2013, 19. [CrossRef]

43. Klymenko, Y.; Johnson, J.; Bos, B.; Lombard, R.; Campbell, L.; Loughran, E.; Stack, M. Heterogeneous Cadherin Expression and Multi-Cellular Aggregate Dynamics in Ovarian Cancer Dissemination. Neoplasia 2017, 19, 549-563. [CrossRef] [PubMed]

44. Sivertsen, S.; Berner, A.; Michael, C.W.; Bedrossian, C.; Davidson, B. Cadherin Expression in Ovarian Carcinoma and Malignant Mesothelioma Cell Effusions. Acta Cytol. 2006, 50, 603. [CrossRef] [PubMed]

45. Klymenko, Y.; Kim, O.; Loughran, E.A.; Yang, J.; Lombard, R.; Alber, M.; Stack, M. Cadherin Composition and Multicellular Aggregate Dynamics in Organotypic Models of Epithelial Ovarian Cancer Intraperitoneal Metastasis. Oncogene 2017. [CrossRef] [PubMed]

46. Shaw, T.J.; Senterman, M.K.; Dawson, K.; Crane, C.A.; Vanderhyden, B.C. Characterization of Intraperitoneal, Orthotopic, and Metastatic Xenograft Models of Human Ovarian Cancer. Mol. Ther. 2004, 10, 1032-1042. [CrossRef] [PubMed]

47. Takai, N.; Jain, A.; Kawamata, N.; Popoviciu, L.M.; Said, J.W.; Whittaker, S.; Miyakawa, I.; Agus, D.B.; Koeffler, H.P. 2C4, a Monoclonal Antibody Against HER2, Disrupts the HER Kinase Signaling Pathway and Inhibits Ovarian Carcinoma Cell Growth. Cancer 2005, 104, 2701-2708. [CrossRef] [PubMed]

48. Afzal, S.; Lalani, E.; Poulsom, R.; Stubbs, A.; Rowlinson, G.; Sato, H.; Seiki, M.; Stamp, G.W.H. MT1-MMP and MMP-2 mRNA Expression in Human Ovarian Tumors: Possible Implications for the Role of Desmoplastic Fibroblasts. Hum. Pathol. 1998, 29, 155-165. [CrossRef]

49. Liu, Y.; Metzinger, M.N.; Lewellen, K.A.; Cripps, S.N.; Carey, K.D.; Harper, E.I.; Shi, Z.; Tarwater, L.; Grisoli, A.; Lee, E.; et al. Obesity Contributes to Ovarian Cancer Metastatic Success through Increased Lipogenesis, Enhanced Vascularity, and Decreased Infiltration of M1 Macrophages. Cancer Res. 2015, 75, 5046-5057. [CrossRef] [PubMed]

50. Mitra, A.K.; Davis, D.A.; Tomar, S.; Roy, L.; Gurler, H.; Xie, J.; Lantvit, D.D.; Cardenas, H.; Fang, F.; Liu, Y.; et al. In Vivo Tumor Growth of High-Grade Serous Ovarian Cancer Cell Lines. Gynecol. Oncol. 2015, 138, 372-377. [CrossRef] [PubMed]

51. Bates, R.C.; Edwards, N.S.; Yates, J.D. Spheroids and Cell Survival. Crit. Rev. Oncol. 2000, 36, 61-74. [CrossRef]

52. Desoize, B.; Jardillier, J. Multicellular Resistance: A Paradigm for Clinical Resistance? Crit. Rev. Oncol. 2000, 36, 193-207. [CrossRef]

53. Frankel, A.; Rosen, K.; Filmus, J.; Kerbel, R.S. Induction of Anoikis and Suppression of Human Ovarian Tumor Growth in Vivo by Down-Regulation of Bcl-X(L). Cancer Res. 2001, 61, 4837-4841. [PubMed] 
54. Green, S.K.; Francia, G.; Isidoro, C.; Kerbel, R.S. Antiadhesive Antibodies Targeting E-Cadherin Sensitize Multicellular Tumor Spheroids to Chemotherapy in Vitro. Mol. Cancer. Ther. 2004, 3, 149-159. [PubMed]

55. Sutherland, R.M. Cell and Environment Interactions in Tumor Microregions: The Multicell Spheroid Model. Science 1988, 240, 177-184. [CrossRef] [PubMed]

56. Latifi, A.; Luwor, R.B.; Bilandzic, M.; Nazaretian, S.; Stenvers, K.; Pyman, J.; Zhu, H.; Thompson, E.W.; Quinn, M.A.; Findlay, J.K. Isolation and Characterization of Tumor Cells from the Ascites of Ovarian Cancer Patients: Molecular Phenotype of Chemoresistant Ovarian Tumors. PLoS ONE 2012, 7, e46858. [CrossRef] [PubMed]

57. Miow, Q.; Tan, T.; Ye, J.; Lau, J.; Yokomizo, T.; Thiery, J.; Mori, S. Epithelial-mesenchymal Status Renders Differential Responses to Cisplatin in Ovarian Cancer. Oncogene 2015, 34, 1899-1907. [CrossRef] [PubMed]

58. Reddy, P.; Liu, L.; Ren, C.; Lindgren, P.; Boman, K.; Shen, Y.; Lundin, E.; Ottander, U.; Rytinki, M.; Liu, K. Formation of E-Cadherin-Mediated Cell-Cell Adhesion Activates AKT and Mitogen Activated Protein Kinase Via Phosphatidylinositol 3 Kinase and Ligand-Independent Activation of Epidermal Growth Factor Receptor in Ovarian Cancer Cells. Mol. Endocrinol. 2005, 19, 2564-2578. [CrossRef] [PubMed]

59. Burkhalter, R.J.; Symowicz, J.; Hudson, L.G.; Gottardi, C.J.; Stack, M.S. Integrin Regulation of Beta-Catenin Signaling in Ovarian Carcinoma. J. Biol. Chem. 2011, 286, 23467-23475. [CrossRef] [PubMed]

60. Liu, Y.; Burkhalter, R.; Symowicz, J.; Chaffin, K.; Ellerbroek, S.; Stack, M.S. Lysophosphatidic Acid Disrupts Junctional Integrity and Epithelial Cohesion in Ovarian Cancer Cells. J. Oncol. 2012, 2012, 501492. [CrossRef] [PubMed]

61. Wu, C.; Cipollone, J.; Maines-Bandiera, S.; Tan, C.; Karsan, A.; Auersperg, N.; Roskelley, C.D. The Morphogenic Function of E-cadherin-mediated Adherens Junctions in Epithelial Ovarian Carcinoma Formation and Progression. Differentiation 2008, 76, 193-205. [CrossRef] [PubMed]

62. Symowicz, J.; Adley, B.P.; Gleason, K.J.; Johnson, J.J.; Ghosh, S.; Fishman, D.A.; Hudson, L.G.; Stack, M.S. Engagement of Collagen-Binding Integrins Promotes Matrix Metalloproteinase-9-Dependent E-Cadherin Ectodomain Shedding in Ovarian Carcinoma Cells. Cancer Res. 2007, 67, 2030-2039. [CrossRef] [PubMed]

63. Gil, O.D.; Lee, C.; Ariztia, E.V.; Wang, F.; Smith, P.J.; Hope, J.M.; Fishman, D.A. Lysophosphatidic Acid (LPA) Promotes E-Cadherin Ectodomain Shedding and OVCA429 Cell Invasion in an uPA-Dependent Manner. Gynecol. Oncol. 2008, 108, 361-369. [CrossRef] [PubMed]

64. Nawrocki-Raby, B.; Gilles, C.; Polette, M.; Bruyneel, E.; Laronze, J.; Bonnet, N.; Foidart, J.; Mareel, M.; Birembaut, P. Upregulation of MMPs by Soluble E-cadherin in Human Lung Tumor Cells. Int. J. Cancer 2003, 105, 790-795. [CrossRef] [PubMed]

65. Marambaud, P.; Shioi, J.; Serban, G.; Georgakopoulos, A.; Sarner, S.; Nagy, V.; Baki, L.; Wen, P.; Efthimiopoulos, S.; Shao, Z.; et al. A Presenilin-1/Gamma-Secretase Cleavage Releases the E-Cadherin Intracellular Domain and Regulates Disassembly of Adherens Junctions. EMBO J. 2002, 21, 1948-1956. [CrossRef] [PubMed]

66. Salahshor, S.; Naidoo, R.; Serra, S.; Shih, W.; Tsao, M.; Chetty, R.; Woodgett, J.R. Frequent Accumulation of Nuclear E-Cadherin and Alterations in the Wnt Signaling Pathway in Esophageal Squamous Cell Carcinomas. Mod. Pathol. 2008, 21, 271-281. [CrossRef] [PubMed]

67. Grabowska, M.M.; Day, M.L. Soluble E-Cadherin: More than a Symptom of Disease. Front. Biosci. 2012, 17, 1948-1964. [CrossRef]

68. Rodriguez, F.J.; Lewis-Tuffin, L.J.; Anastasiadis, P.Z. E-Cadherin's Dark Side: Possible Role in Tumor Progression. Biochim. Biophys. Acta Rev. Cancer 2012, 1826, 23-31. [CrossRef] [PubMed]

69. Jolly, M.K.; Boareto, M.; Huang, B.; Jia, D.; Lu, M.; Ben-Jacob, E.; Onuchic, J.N.; Levine, H. Implications of the Hybrid Epithelial/Mesenchymal Phenotype in Metastasis. Front. Oncol. 2015, 5. [CrossRef] [PubMed]

70. Tam, W.L.; Weinberg, R.A. The Epigenetics of Epithelial-Mesenchymal Plasticity in Cancer. Nat. Med. 2013, 19, 1438-1449. [CrossRef] [PubMed]

71. Huang, R.Y.; Wong, M.; Tan, T.; Kuay, K.; Ng, A.; Chung, V.; Chu, Y.; Matsumura, N.; Lai, H.; Lee, Y. An EMT Spectrum Defines an Anoikis-Resistant and Spheroidogenic Intermediate Mesenchymal State that is Sensitive to E-Cadherin Restoration by a Src-Kinase Inhibitor, Saracatinib (AZD0530). Cell Death Dis. 2013, 4, e915. [CrossRef] [PubMed]

72. Jolly, M.K.; Tripathi, S.C.; Jia, D.; Mooney, S.M.; Celiktas, M.; Hanash, S.M.; Mani, S.A.; Pienta, K.J.; Ben-Jacob, E.; Levine, H. Stability of the Hybrid Epithelial/Mesenchymal Phenotype. Oncotarget 2016, 7, 27067-27084. [CrossRef] [PubMed] 
73. Chao, Y.; Wu, Q.; Acquafondata, M.; Dhir, R.; Wells, A. Partial Mesenchymal to Epithelial Reverting Transition in Breast and Prostate Cancer Metastases. Cancer Microenviron. 2012, 5, 19-28. [CrossRef] [PubMed]

74. Hecht, I.; Bar-El, Y.; Balmer, F.; Natan, S.; Tsarfaty, I.; Schweitzer, F.; Ben-Jacob, E. Tumor Invasion Optimization by Mesenchymal-Amoeboid Heterogeneity. Sci. Rep. 2015, 5. [CrossRef] [PubMed]

75. Friedl, P.; Wolf, K. Plasticity of Cell Migration: A Multiscale Tuning Model. J. Cell Biol. 2010, 188, 11-19. [CrossRef] [PubMed]

76. Andriani, F.; Bertolini, G.; Facchinetti, F.; Baldoli, E.; Moro, M.; Casalini, P.; Caserini, R.; Milione, M.; Leone, G.; Pelosi, G. Conversion to Stem-cell State in Response to Microenvironmental Cues is Regulated by Balance between Epithelial and Mesenchymal Features in Lung Cancer Cells. Mol. Oncol. 2016, 10, $253-271$. [CrossRef] [PubMed]

77. Bastos, L.G.D.R.; de Marcondes, P.G.; de-Freitas-Junior, J.C.M.; Leve, F.; Mencalha, A.L.; de Souza, W.F.; de Araujo, W.M.; Tanaka, M.N.; Abdelhay, E.S.F.W.; Morgado-Díaz, J.A. Progeny from Irradiated Colorectal Cancer Cells Acquire an EMT-Like Phenotype and Activate Wnt/ $\beta$-Catenin Pathway. J. Cell. Biochem. 2014, 115, 2175-2187. [CrossRef] [PubMed]

78. Hiscox, S.; Jiang, W.G.; Obermeier, K.; Taylor, K.; Morgan, L.; Burmi, R.; Barrow, D.; Nicholson, R.I. Tamoxifen Resistance in MCF7 Cells Promotes EMT-like Behaviour and Involves Modulation of B-catenin Phosphorylation. Int. J. Cancer 2006, 118, 290-301. [CrossRef] [PubMed]

79. Wu, Y.; Ginther, C.; Kim, J.; Mosher, N.; Chung, S.; Slamon, D.; Vadgama, J.V. Expression of Wnt3 Activates Wnt/Beta-Catenin Pathway and Promotes EMT-Like Phenotype in Trastuzumab-Resistant HER2-Overexpressing Breast Cancer Cells. Mol. Cancer. Res. 2012, 10, 1597-1606. [CrossRef] [PubMed]

80. Grosse-Wilde, A.; d'Hérouël, A.F.; McIntosh, E.; Ertaylan, G.; Skupin, A.; Kuestner, R.E.; del Sol, A.; Walters, K.; Huang, S. Stemness of the Hybrid Epithelial/Mesenchymal State in Breast Cancer and its Association with Poor Survival. PLoS ONE 2015, 10, e0126522. [CrossRef] [PubMed]

81. Strauss, R.; Li, Z.; Liu, Y.; Beyer, I.; Persson, J.; Sova, P.; Möller, T.; Pesonen, S.; Hemminki, A.; Hamerlik, P. Analysis of Epithelial and Mesenchymal Markers in Ovarian Cancer Reveals Phenotypic Heterogeneity and Plasticity. PLoS ONE 2011, 6, e16186. [CrossRef]

82. Ruscetti, M.; Quach, B.; Dadashian, E.L.; Mulholland, D.J.; Wu, H. Tracking and Functional Characterization of Epithelial-Mesenchymal Transition and Mesenchymal Tumor Cells during Prostate Cancer Metastasis. Cancer Res. 2015, 75, 2749-2759. [CrossRef] [PubMed]

83. Mills, G.B.; Moolenaar, W.H. The Emerging Role of Lysophosphatidic Acid in Cancer. Nat. Rev. Cancer 2003, 3, 582-591. [CrossRef] [PubMed]

84. Mills, G.B.; Eder, A.; Fang, X.; Hasegawa, Y.; Mao, M.; Lu, Y.; Tanyi, J.; Tabassam, F.H.; Wiener, J.; Lapushin, R. Critical role of lysophospholipids in the pathophysiology, diagnosis, and management of ovarian cancer. In Ovarian Cancer; Springer: New York, NY, USA, 2002; pp. 259-283.

85. Baker, D.L.; Morrison, P.; Miller, B.; Riely, C.A.; Tolley, B.; Westermann, A.M.; Bonfrer, J.M.; Bais, E.; Moolenaar, W.H.; Tigyi, G. Plasma Lysophosphatidic Acid Concentration and Ovarian Cancer. JAMA 2002, 287, 3081-3082. [CrossRef] [PubMed]

86. Xu, Y.; Shen, Z.; Wiper, D.W.; Wu, M.; Morton, R.E.; Elson, P.; Kennedy, A.W.; Belinson, J.; Markman, M.; Casey, G. Lysophosphatidic Acid as a Potential Biomarker for Ovarian and Other Gynecologic Cancers. JAMA 1998, 280, 719-723. [CrossRef] [PubMed]

87. Westermann, A.M.; Havik, E.; Postma, F.R.; Beijnen, J.H.; Dalesio, O.; Moolenaar, W.H.; Rodenhuis, S. Malignant Effusions Contain Lysophosphatidic Acid (LPA)-Like Activity. Ann. Oncol. 1998, 9, 437-442. [CrossRef] [PubMed]

88. Sutphen, R.; Xu, Y.; Wilbanks, G.D.; Fiorica, J.; Grendys, E.C., Jr.; LaPolla, J.P.; Arango, H.; Hoffman, M.S.; Martino, M.; Wakeley, K.; et al. Lysophospholipids are Potential Biomarkers of Ovarian Cancer. Cancer Epidemiol. Prev. Biomark. 2004, 13, 1185-1191.

89. Ren, J.; Xiao, Y.J.; Singh, L.S.; Zhao, X.; Zhao, Z.; Feng, L.; Rose, T.M.; Prestwich, G.D.; Xu, Y. Lysophosphatidic Acid is Constitutively Produced by Human Peritoneal Mesothelial Cells and Enhances Adhesion, Migration, and Invasion of Ovarian Cancer Cells. Cancer Res. 2006, 66, 3006-3014. [CrossRef] [PubMed]

90. Do, T.V.; Symowicz, J.C.; Berman, D.M.; Liotta, L.A.; Petricoin, E.F.; Stack, M.S.; Fishman, D.A. Lysophosphatidic Acid Down-Regulates Stress Fibers and Up-Regulates Pro-Matrix Metalloproteinase-2 Activation in Ovarian Cancer Cells. Mol. Cancer Res. 2007, 5, 121-131. [CrossRef] [PubMed] 
91. Fishman, D.A.; Liu, Y.; Ellerbroek, S.M.; Stack, M.S. Lysophosphatidic Acid Promotes Matrix Metalloproteinase (MMP) Activation and MMP-Dependent Invasion in Ovarian Cancer Cells. Cancer Res. 2001, 61, 3194-3199. [PubMed]

92. Burkhalter, R.J.; Westfall, S.D.; Liu, Y.; Stack, M.S. Lysophosphatidic Acid Initiates Epithelial to Mesenchymal Transition and Induces Beta-Catenin-Mediated Transcription in Epithelial Ovarian Carcinoma. J. Biol. Chem. 2015, 290, 22143-22154. [CrossRef] [PubMed]

93. Ray, U.; Roy, S.S.; Chowdhury, S.R. Lysophosphatidic Acid Promotes Epithelial to Mesenchymal Transition in Ovarian Cancer Cells by Repressing SIRT1. Cell. Physiol. Biochem. 2017, 41, 795-805. [CrossRef] [PubMed]

94. Ha, J.H.; Ward, J.D.; Radhakrishnan, R.; Jayaraman, M.; Song, Y.S.; Dhanasekaran, D.N. Lysophosphatidic Acid Stimulates Epithelial to Mesenchymal Transition Marker Slug/Snail2 in Ovarian Cancer Cells Via Galphai2, Src, and HIF1alpha Signaling Nexus. Oncotarget 2016, 7, 37664-37679. [CrossRef] [PubMed]

95. Vergara, D.; Merlot, B.; Lucot, J.; Collinet, P.; Vinatier, D.; Fournier, I.; Salzet, M. Epithelial-mesenchymal Transition in Ovarian Cancer. Cancer Lett. 2010, 291, 59-66. [CrossRef] [PubMed]

96. Xu, Z.; Jiang, Y.; Steed, H.; Davidge, S.; Fu, Y. TGF $\beta$ and EGF Synergistically Induce a More Invasive Phenotype of Epithelial Ovarian Cancer Cells. Biochem. Biophys. Res. Commun. 2010, 401, 376-381. [CrossRef] [PubMed]

97. Thiery, J.P.; Sleeman, J.P. Complex Networks Orchestrate Epithelial-mesenchymal Transitions. Nat. Rev. Mol. Cell Boil. 2006, 7, 131-142. [CrossRef] [PubMed]

98. Thiery, J.P.; Acloque, H.; Huang, R.Y.; Nieto, M.A. Epithelial-Mesenchymal Transitions in Development and Disease. Cell 2009, 139, 871-890. [CrossRef] [PubMed]

99. Liu, Y.; Sun, X.; Feng, J.; Deng, L.L.; Liu, Y.; Li, B.; Zhu, M.; Lu, C.; Zhou, L. MT2-MMP Induces Proteolysis and Leads to EMT in Carcinomas. Oncotarget 2016, 7, 48193-48205. [CrossRef] [PubMed]

100. Dahl, K.D.C.; Symowicz, J.; Ning, Y.; Gutierrez, E.; Fishman, D.A.; Adley, B.P.; Stack, M.S.; Hudson, L.G. Matrix Metalloproteinase 9 is a Mediator of Epidermal Growth Factor-Dependent E-Cadherin Loss in Ovarian Carcinoma Cells. Cancer Res. 2008, 68, 4606-4613. [CrossRef] [PubMed]

101. Covington, M.D.; Burghardt, R.C.; Parrish, A.R. Ischemia-Induced Cleavage of Cadherins in NRK Cells Requires MT1-MMP (MMP-14). Am. J. Physiol. Renal Physiol. 2006, 290, F43-F51. [CrossRef] [PubMed]

102. Lochter, A.; Galosy, S.; Muschler, J.; Freedman, N.; Werb, Z.; Bissell, M.J. Matrix Metalloproteinase Stromelysin-1 Triggers a Cascade of Molecular Alterations that Leads to Stable Epithelial-to-Mesenchymal Conversion and a Premalignant Phenotype in Mammary Epithelial Cells. J. Cell Biol. 1997, 139, 1861-1872. [CrossRef] [PubMed]

103. Noe, V.; Fingleton, B.; Jacobs, K.; Crawford, H.C.; Vermeulen, S.; Steelant, W.; Bruyneel, E.; Matrisian, L.M.; Mareel, M. Release of an Invasion Promoter E-Cadherin Fragment by Matrilysin and Stromelysin-1. J. Cell. Sci. 2001, 114, 111-118. [PubMed]

104. Kessenbrock, K.; Plaks, V.; Werb, Z. Matrix Metalloproteinases: Regulators of the Tumor Microenvironment. Cell 2010, 141, 52-67. [CrossRef] [PubMed]

105. Rowe, R.G.; Weiss, S.J. Navigating ECM Barriers at the Invasive Front: The Cancer Cell-stroma Interface. Ann. Rev. Cell Dev. 2009, 25, 567-595. [CrossRef] [PubMed]

106. Itoh, Y. Membrane-Type Matrix Metalloproteinases: Their Functions and Regulations. Matrix Biol. 2015, 44, 207-223. [CrossRef] [PubMed]

107. Yokoyama, K.; Kamata, N.; Fujimoto, R.; Tsutsumi, S.; Tomonari, M.; Taki, M.; Hosokawa, H.; Nagayama, M. Increased Invasion and Matrix Metalloproteinase-2 Expression by Snail-Induced Mesenchymal Transition in Squamous Cell Carcinomas. Int. J. Oncol. 2003, 22, 891-898. [CrossRef] [PubMed]

108. Brabletz, T.; Jung, A.; Dag, S.; Hlubek, F.; Kirchner, T. B-Catenin Regulates the Expression of the Matrix Metalloproteinase-7 in Human Colorectal Cancer. Am. J. Pathol. 1999, 155, 1033-1038. [CrossRef]

109. Crawford, H.C.; Fingleton, B.; Gustavson, M.D.; Kurpios, N.; Wagenaar, R.A.; Hassell, J.A.; Matrisian, L.M. The PEA3 Subfamily of Ets Transcription Factors Synergizes with Beta-Catenin-LEF-1 to Activate Matrilysin Transcription in Intestinal Tumors. Mol. Cell. Biol. 2001, 21, 1370-1383. [CrossRef] [PubMed]

110. Takahashi, M.; Tsunoda, T.; Seiki, M.; Nakamura, Y.; Furukawa, Y. Identification of Membrane-Type Matrix Metalloproteinase-1 as a Target of the [Beta]-Catenin/Tcf4 Complex in Human Colorectal Cancers. Oncogene 2002, 21, 5861. [CrossRef] [PubMed]

111. Turunen, S.P.; Tatti-Bugaeva, O.; Lehti, K. Membrane-Type Matrix Metalloproteases as Diverse Effectors of Cancer Progression. Biochim. Biophys. Acta Mol. Cell Res. 2017. [CrossRef] [PubMed] 
112. Gilles, C.; Newgreen, D.F.; Sato, H.; Thompson, E.W. Matrix Metalloproteases and Epithelial-to-Mesenchymal Transition. In Rise and Fall of Epithelial Phenotype; Springer: New York, NY, USA, 2005; pp. 297-315.

113. Roy, R.; Yang, J.; Moses, M.A. Matrix Metalloproteinases as Novel Biomarker s and Potential Therapeutic Targets in Human Cancer. J. Clin. Oncol. 2009, 27, 5287-5297. [CrossRef] [PubMed]

114. Milliken, D.; Scotton, C.; Raju, S.; Balkwill, F.; Wilson, J. Analysis of Chemokines and Chemokine Receptor Expression in Ovarian Cancer Ascites. Clin. Cancer Res. 2002, 8, 1108-1114. [PubMed]

115. Matte, I.; Lane, D.; Laplante, C.; Rancourt, C.; Piché, A. Profiling of Cytokines in Human Epithelial Ovarian Cancer Ascites. Am. J. Cancer Res. 2012, 2, 566-580. [PubMed]

116. Penson, R.T.; Kronish, K.; Duan, Z.; Feller, A.J.; Stark, P.; Cook, S.E.; Duska, L.R.; Fuller, A.F.; Goodman, A.; Nikrui, N. Cytokines IL-1 $\beta$, IL-2, IL-6, IL-8, MCP-1, GM-CSF and TNF $\alpha$ in Patients with Epithelial Ovarian Cancer and their Relationship to Treatment with Paclitaxel. Int. J. Gynecol. Cancer 2000, 10, 33-41. [CrossRef] [PubMed]

117. Kipps, E.; Tan, D.S.; Kaye, S.B. Meeting the Challenge of Ascites in Ovarian Cancer: New Avenues for Therapy and Research. Nat. Rev. Cancer 2013, 13, 273-282. [CrossRef] [PubMed]

118. Yin, J.; Zeng, F.; Wu, N.; Kang, K.; Yang, Z.; Yang, H. Interleukin-8 Promotes Human Ovarian Cancer Cell Migration by Epithelial-mesenchymal Transition Induction in Vitro. Clin. Transl. Oncol. 2015, 17, 365-370. [CrossRef] [PubMed]

119. So, K.A.; Min, K.J.; Hong, J.H.; Lee, J. Interleukin-6 Expression by Interactions between Gynecologic Cancer Cells and Human Mesenchymal Stem Cells Promotes Epithelial-Mesenchymal Transition. Int. J. Oncol. 2015, 47, 1451-1459. [CrossRef] [PubMed]

120. Bharti, R.; Dey, G.; Mandal, M. Cancer Development, Chemoresistance, Epithelial to Mesenchymal Transition and Stem Cells: A Snapshot of IL-6 Mediated Involvement. Cancer Lett. 2016, 375, 51-61. [CrossRef] [PubMed]

121. Fang, X.; Yu, S.; Bast, R.C.; Liu, S.; Xu, H.J.; Hu, S.X.; LaPushin, R.; Claret, F.X.; Aggarwal, B.B.; Lu, Y.; et al. Mechanisms for Lysophosphatidic Acid-Induced Cytokine Production in Ovarian Cancer Cells. J. Biol. Chem. 2004, 279, 9653-9661. [CrossRef] [PubMed]

122. Long, H.; Xiang, T.; Qi, W.; Huang, J.; Chen, J.; He, L.; Liang, Z.; Guo, B.; Li, Y.; Xie, R.; et al. CD133+ Ovarian Cancer Stem-Like Cells Promote Non-Stem Cancer Cell Metastasis Via CCL5 Induced Epithelial-Mesenchymal Transition. Oncotarget 2015, 6, 5846-5859. [CrossRef] [PubMed]

123. Cheng, S.; Han, L.; Guo, J.; Yang, Q.; Zhou, J.; Yang, X. The Essential Roles of CCR7 in Epithelial-to-Mesenchymal Transition Induced by Hypoxia in Epithelial Ovarian Carcinomas. Tumor Biol. 2014, 35, 12293-12298. [CrossRef] [PubMed]

124. Comamala, M.; Pinard, M.; Theriault, C.; Matte, I.; Albert, A.; Boivin, M.; Beaudin, J.; Piche, A.; Rancourt, C. Downregulation of Cell Surface CA125/MUC16 Induces Epithelial-to-Mesenchymal Transition and Restores EGFR Signalling in NIH: OVCAR3 Ovarian Carcinoma Cells. Br. J. Cancer 2011, 104, 989-999. [CrossRef] [PubMed]

125. Thériault, C.; Pinard, M.; Comamala, M.; Migneault, M.; Beaudin, J.; Matte, I.; Boivin, M.; Piché, A.; Rancourt, C. MUC16 (CA125) Regulates Epithelial Ovarian Cancer Cell Growth, Tumorigenesis and Metastasis. Gynecol. Oncol. 2011, 121, 434-443. [CrossRef] [PubMed]

126. Asem, M.S.; Buechler, S.; Wates, R.B.; Miller, D.L.; Stack, M.S. Wnt5a Signaling in Cancer. Cancers 2016, 8, 79. [CrossRef] [PubMed]

127. Qi, H.; Sun, B.; Zhao, X.; Du, J.; Gu, Q.; Liu, Y.; Cheng, R.; Dong, X. Wnt5a Promotes Vasculogenic Mimicry and Epithelial-Mesenchymal Transition Via Protein Kinase C $\alpha$ in Epithelial Ovarian Cancer. Oncol. Rep. 2014, 32, 771-779. [CrossRef] [PubMed]

128. Serrano-Gomez, S.J.; Maziveyi, M.; Alahari, S.K. Regulation of Epithelial-Mesenchymal Transition through Epigenetic and Post-Translational Modifications. Mol. Cancer 2016, 15, 18. [CrossRef] [PubMed]

129. Graff, J.R.; Herman, J.G.; Lapidus, R.G.; Chopra, H.; Xu, R.; Jarrard, D.F.; Isaacs, W.B.; Pitha, P.M.; Davidson, N.E.; Baylin, S.B. E-Cadherin Expression is Silenced by DNA Hypermethylation in Human Breast and Prostate Carcinomas. Cancer Res. 1995, 55, 5195-5199. [PubMed]

130. Bornman, D.M.; Mathew, S.; Alsruhe, J.; Herman, J.G.; Gabrielson, E. Methylation of the E-Cadherin Gene in Bladder Neoplasia and in Normal Urothelial Epithelium from Elderly Individuals. Am. J. Pathol. 2001, 159, 831-835. [CrossRef] 
131. Tamura, G.; Yin, J.; Wang, S.; Fleisher, A.S.; Zou, T.; Abraham, J.M.; Kong, D.; Smolinski, K.N.; Wilson, K.T.; James, S.P.; et al. E-Cadherin Gene Promoter Hypermethylation in Primary Human Gastric Carcinomas. J. Natl. Cancer Inst. 2000, 92, 569-573. [CrossRef] [PubMed]

132. Fukagawa, A.; Ishii, H.; Miyazawa, K.; Saitoh, M. $\delta$ EF1 Associates with DNMT1 and Maintains DNA Methylation of the E-cadherin Promoter in Breast Cancer Cells. Cancer Med. 2015, 4, 125-135. [CrossRef] [PubMed]

133. Kassambara, A.; Klein, B.; Moreaux, J. MMSET is overexpressed in Cancers: Link with Tumor Aggressiveness. Biochem. Biophys. Res. Commun. 2009, 379, 840-845. [CrossRef] [PubMed]

134. Dong, C.; Wu, Y.; Yao, J.; Wang, Y.; Yu, Y.; Rychahou, P.G.; Evers, B.M.; Zhou, B.P. G9a Interacts with Snail and is Critical for Snail-Mediated E-Cadherin Repression in Human Breast Cancer. J. Clin. Invest. 2012, 122, 1469-1486. [CrossRef] [PubMed]

135. Dong, C.; Wu, Y.; Wang, Y.; Wang, C.; Kang, T.; Rychahou, P.G.; Chi, Y.; Evers, B.M.; Zhou, B.P. Interaction with Suv39H1 is Critical for Snail-Mediated E-Cadherin Repression in Breast Cancer. Oncogene 2013, 32, 1351-1362. [CrossRef] [PubMed]

136. Jorgensen, S.; Elvers, I.; Trelle, M.B.; Menzel, T.; Eskildsen, M.; Jensen, O.N.; Helleday, T.; Helin, K.; Sorensen, C.S. The Histone Methyltransferase SET8 is Required for S-Phase Progression. J. Cell Biol. 2007, 179, 1337-1345. [CrossRef] [PubMed]

137. Peinado, H.; Ballestar, E.; Esteller, M.; Cano, A. Snail Mediates E-Cadherin Repression by the Recruitment of the Sin3A/Histone Deacetylase 1 (HDAC1)/HDAC2 Complex. Mol. Cell. Biol. 2004, 24, 306-319. [CrossRef] [PubMed]

138. Aghdassi, A.; Sendler, M.; Guenther, A.; Mayerle, J.; Behn, C.O.; Heidecke, C.D.; Friess, H.; Buchler, M.; Evert, M.; Lerch, M.M.; et al. Recruitment of Histone Deacetylases HDAC1 and HDAC2 by the Transcriptional Repressor ZEB1 Downregulates E-Cadherin Expression in Pancreatic Cancer. Gut 2012, 61, 439-448. [CrossRef] [PubMed]

139. Fu, J.; Qin, L.; He, T.; Qin, J.; Hong, J.; Wong, J.; Liao, L.; Xu, J. The TWIST/Mi2/NuRD Protein Complex and its Essential Role in Cancer Metastasis. Cell Res. 2011, 21, 275-289. [CrossRef] [PubMed]

140. Adhikary, A.; Chakraborty, S.; Mazumdar, M.; Ghosh, S.; Mukherjee, S.; Manna, A.; Mohanty, S.; Nakka, K.K.; Joshi, S.; De, A.; et al. Inhibition of Epithelial to Mesenchymal Transition by E-Cadherin Up-Regulation Via Repression of Slug Transcription and Inhibition of E-Cadherin Degradation: Dual Role of Scaffold/Matrix Attachment Region-Binding Protein 1 (SMAR1) in Breast Cancer Cells. J. Biol. Chem. 2014, 289, 25431-25444. [CrossRef] [PubMed]

141. Longacre, M.; Snyder, N.A.; Housman, G.; Leary, M.; Lapinska, K.; Heerboth, S.; Willbanks, A.; Sarkar, S. A Comparative Analysis of Genetic and Epigenetic Events of Breast and Ovarian Cancer Related to Tumorigenesis. Int. J. Mol. Sci. 2016, 17, 759. [CrossRef] [PubMed]

142. Cardenas, H.; Vieth, E.; Lee, J.; Segar, M.; Liu, Y.; Nephew, K.P.; Matei, D. TGF-B Induces Global Changes in DNA Methylation during the Epithelial-to-Mesenchymal Transition in Ovarian Cancer Cells. Epigenetics 2014, 9, 1461-1472. [CrossRef] [PubMed]

143. Su, H.; Lai, H.; Lin, Y.; Liu, C.; Chen, C.; Chou, Y.; Lin, S.; Lin, W.; Lee, H.; Yu, M. Epigenetic Silencing of SFRP5 is Related to Malignant Phenotype and Chemoresistance of Ovarian Cancer through Wnt Signaling Pathway. Int. J. Cancer 2010, 127, 555-567. [CrossRef] [PubMed]

144. Deng, Z.; Wang, L.; Hou, H.; Zhou, J.; Li, X. Epigenetic Regulation of IQGAP2 Promotes Ovarian Cancer Progression Via Activating Wnt/B-Catenin Signaling. Int. J. Oncol. 2016, 48, 153-160. [CrossRef] [PubMed]

145. Smith, H.J.; Straughn, J.M.; Buchsbaum, D.J.; Arend, R.C. Epigenetic Therapy for the Treatment of Epithelial Ovarian Cancer: A Clinical Review. Gynecol. Oncol. Rep. 2017, 20, 81-86. [CrossRef] [PubMed]

146. Gloss, B.S.; Samimi, G. Epigenetic Biomarkers in Epithelial Ovarian Cancer. Cancer Lett. 2014, 342, $257-263$. [CrossRef] [PubMed]

147. Wang, Y.; Cardenas, H.; Fang, F.; Condello, S.; Taverna, P.; Segar, M.; Liu, Y.; Nephew, K.P.; Matei, D. Epigenetic Targeting of Ovarian Cancer Stem Cells. Cancer Res. 2014, 74, 4922-4936. [CrossRef] [PubMed]

148. Zhou, B.P.; Deng, J.; Xia, W.; Xu, J.; Li, Y.M.; Gunduz, M.; Hung, M. Dual Regulation of Snail by GSK-3 $\beta$-Mediated Phosphorylation in Control of Epithelial-mesenchymal Transition. Nat. Cell Biol. 2004, 6, 931-940. [CrossRef] [PubMed] 
149. Du, C.; Zhang, C.; Hassan, S.; Biswas, M.H.; Balaji, K.C. Protein Kinase D1 Suppresses Epithelial-to-Mesenchymal Transition through Phosphorylation of Snail. Cancer Res. 2010, 70, 7810-7819. [CrossRef] [PubMed]

150. Zheng, H.; Shen, M.; Zha, Y.; Li, W.; Wei, Y.; Blanco, M.A.; Ren, G.; Zhou, T.; Storz, P.; Wang, H. PKD1 Phosphorylation-Dependent Degradation of SNAIL by SCF-FBXO11 Regulates Epithelial-Mesenchymal Transition and Metastasis. Cancer Cell 2014, 26, 358-373. [CrossRef] [PubMed]

151. Park, S.Y.; Kim, H.S.; Kim, N.H.; Ji, S.; Cha, S.Y.; Kang, J.G.; Ota, I.; Shimada, K.; Konishi, N.; Nam, H.W.; et al. Snail1 is Stabilized by O-GlcNAc Modification in Hyperglycaemic Condition. EMBO J. 2010, 29, 3787-3796. [CrossRef] [PubMed]

152. Yang, C.; Chen, H.; Tan, G.; Gao, W.; Cheng, L.; Jiang, X.; Yu, L.; Tan, Y. FOXM1 Promotes the Epithelial to Mesenchymal Transition by Stimulating the Transcription of Slug in Human Breast Cancer. Cancer Lett. 2013, 340, 104-112. [CrossRef] [PubMed]

153. Bao, B.; Wang, Z.; Ali, S.; Kong, D.; Banerjee, S.; Ahmad, A.; Li, Y.; Azmi, A.S.; Miele, L.; Sarkar, F.H. Over-expression of FoxM1 Leads to Epithelial-mesenchymal Transition and Cancer Stem Cell Phenotype in Pancreatic Cancer Cells. J. Cell. Biochem. 2011, 112, 2296-2306. [CrossRef] [PubMed]

154. Long, J.; Zuo, D.; Park, M. Pc2-Mediated Sumoylation of Smad-Interacting Protein 1 Attenuates Transcriptional Repression of E-Cadherin. J. Biol. Chem. 2005, 280, 35477-35489. [CrossRef] [PubMed]

155. He, M.; Zhou, Z.; Shah, A.A.; Hong, Y.; Chen, Q.; Wan, Y. New Insights into Posttranslational Modifications of Hippo Pathway in Carcinogenesis and Therapeutics. Cell Div. 2016, 11, 4. [CrossRef] [PubMed]

156. Hall, C.A.; Wang, R.; Miao, J.; Oliva, E.; Shen, X.; Wheeler, T.; Hilsenbeck, S.G.; Orsulic, S.; Goode, S. Hippo Pathway Effector Yap is an Ovarian Cancer Oncogene. Cancer Res. 2010, 70, 8517-8525. [CrossRef] [PubMed]

157. Zhang, J.; Ma, L. MicroRNA Control of Epithelial-mesenchymal Transition and Metastasis. Cancer Metastasis Rev. 2012, 31, 653-662. [CrossRef] [PubMed]

158. Abba, M.L.; Patil, N.; Leupold, J.H.; Allgayer, H. MicroRNA Regulation of Epithelial to Mesenchymal Transition. J. Clin. Med. 2016, 5, 8. [CrossRef] [PubMed]

159. Gregory, P.A.; Bert, A.G.; Paterson, E.L.; Barry, S.C.; Tsykin, A.; Farshid, G.; Vadas, M.A.; Khew-Goodall, Y.; Goodall, G.J. The miR-200 Family and miR-205 Regulate Epithelial to Mesenchymal Transition by Targeting ZEB1 and SIP1. Nat. Cell Biol. 2008, 10, 593-601. [CrossRef] [PubMed]

160. Park, S.M.; Gaur, A.B.; Lengyel, E.; Peter, M.E. The miR-200 Family Determines the Epithelial Phenotype of Cancer Cells by Targeting the E-Cadherin Repressors ZEB1 and ZEB2. Genes Dev. 2008, 22, 894-907. [CrossRef] [PubMed]

161. Wiklund, E.D.; Bramsen, J.B.; Hulf, T.; Dyrskjøt, L.; Ramanathan, R.; Hansen, T.B.; Villadsen, S.B.; Gao, S.; Ostenfeld, M.S.; Borre, M. Coordinated Epigenetic Repression of the miR-200 Family and miR-205 in Invasive Bladder Cancer. Int. J. Cancer 2011, 128, 1327-1334. [CrossRef] [PubMed]

162. Fu, W.; Tao, T.; Qi, M.; Wang, L.; Hu, J.; Li, X.; Xing, N.; Du, R.; Han, B. MicroRNA-132/212 Upregulation Inhibits TGF- $\beta$-Mediated Epithelial-Mesenchymal Transition of Prostate Cancer Cells by Targeting SOX4. Prostate 2016, 76, 1560-1570. [CrossRef] [PubMed]

163. Zhao, J.; Zhang, L.; Guo, X.; Wang, J.; Zhou, W.; Liu, M.; Li, X.; Tang, H. miR-212/132 Downregulates SMAD2 Expression to Suppress the G1/S Phase Transition of the Cell Cycle and the Epithelial to Mesenchymal Transition in Cervical Cancer Cells. IUBMB Life 2015, 67, 380-394. [CrossRef] [PubMed]

164. Zheng, Y.; Luo, H.; Shi, Q.; Hao, Z.; Ding, Y.; Wang, Q.; Li, S.; Xiao, G.; Tong, S. miR-132 Inhibits Colorectal Cancer Invasion and Metastasis Via Directly Targeting ZEB2. World J. Gastroenterol. 2014, 20, 6515-6522. [CrossRef] [PubMed]

165. You, J.; Li, Y.; Fang, N.; Liu, B.; Zu, L.; Chang, R.; Li, X.; Zhou, Q. MiR-132 Suppresses the Migration and Invasion of Lung Cancer Cells Via Targeting the EMT Regulator ZEB2. PLoS ONE 2014, 9, e91827. [CrossRef] [PubMed]

166. Zhang, J.X.; Zhai, J.F.; Yang, X.T.; Wang, J. MicroRNA-132 Inhibits Migration, Invasion and Epithelial-Mesenchymal Transition by Regulating TGFbeta1/Smad2 in Human Non-Small Cell Lung Cancer. Eur. Rev. Med. Pharmacol. Sci. 2016, 20, 3793-3801. [PubMed]

167. Li, H.; Ouyang, R.; Wang, Z.; Zhou, W.; Chen, H.; Jiang, Y.; Zhang, Y.; Liao, M.; Wang, W.; Ye, M. MiR-150 Promotes Cellular Metastasis in Non-Small Cell Lung Cancer by Targeting FOXO4. Sci. Rep. 2016, 6, 39001. [CrossRef] [PubMed] 
168. Yokobori, T.; Suzuki, S.; Tanaka, N.; Inose, T.; Sohda, M.; Sano, A.; Sakai, M.; Nakajima, M.; Miyazaki, T.; Kato, H. MiR-150 is Associated with Poor Prognosis in Esophageal Squamous Cell Carcinoma Via Targeting the EMT Inducer ZEB1. Cancer Sci. 2013, 104, 48-54. [CrossRef] [PubMed]

169. Ma, L.; Young, J.; Prabhala, H.; Pan, E.; Mestdagh, P.; Muth, D.; Teruya-Feldstein, J.; Reinhardt, F.; Onder, T.T.; Valastyan, S. miR-9, a MYC/MYCN-Activated microRNA, Regulates E-Cadherin and Cancer Metastasis. Nat. Cell Biol. 2010, 12, 247-256. [CrossRef] [PubMed]

170. Hu, J.; Qiu, M.; Jiang, F.; Zhang, S.; Yang, X.; Wang, J.; Xu, L.; Yin, R. MiR-145 Regulates Cancer Stem-Like Properties and Epithelial-to-Mesenchymal Transition in Lung Adenocarcinoma-Initiating Cells. Tumor Biol. 2014, 35, 8953-8961. [CrossRef] [PubMed]

171. Hu, H.; Xu, Z.; Li, C.; Xu, C.; Lei, Z.; Zhang, H.; Zhao, J. MiR-145 and miR-203 Represses TGF-B-Induced Epithelial-Mesenchymal Transition and Invasion by Inhibiting SMAD3 in Non-Small Cell Lung Cancer Cells. Lung Cancer 2016, 97, 87-94. [CrossRef] [PubMed]

172. Zhang, Z.; Liu, S.; Shi, R.; Zhao, G. miR-27 Promotes Human Gastric Cancer Cell Metastasis by Inducing Epithelial-to-Mesenchymal Transition. Cancer Genet. 2011, 204, 486-491. [CrossRef] [PubMed]

173. Li, J.; Wang, Y.; Song, Y.; Fu, Z.; Yu, W. miR-27a Regulates Cisplatin Resistance and Metastasis by Targeting RKIP in Human Lung Adenocarcinoma Cells. Mol. Cancer 2014, 13, 193. [CrossRef] [PubMed]

174. Pei, Y.; Lei, Y.; Liu, X. MiR-29a Promotes Cell Proliferation and EMT in Breast Cancer by Targeting Ten Eleven Translocation 1. Biochim. Biophys. Acta Mol. Basis Dis. 2016, 1862, 2177-2185. [CrossRef] [PubMed]

175. Gebeshuber, C.A.; Zatloukal, K.; Martinez, J. miR-29a Suppresses Tristetraprolin, which is a Regulator of Epithelial Polarity and Metastasis. EMBO Rep. 2009, 10, 400-405. [CrossRef] [PubMed]

176. Jiang, H.; Zhang, G.; Wu, J.; Jiang, C. Diverse Roles of miR-29 in Cancer (Review). Oncol. Rep. 2014, 31, 1509-1516. [CrossRef] [PubMed]

177. Zheng, Y.; Xiao, K.; Xiao, G.; Tong, S.; Ding, Y.; Wang, Q.; Li, S.; Hao, Z. MicroRNA-103 Promotes Tumor Growth and Metastasis in Colorectal Cancer by Directly Targeting LATS2. Oncol. Lett. 2016, 12, 2194-2200. [CrossRef] [PubMed]

178. Chen, H.Y.; Lin, Y.M.; Chung, H.C.; Lang, Y.D.; Lin, C.J.; Huang, J.; Wang, W.C.; Lin, F.M.; Chen, Z.; Huang, H.D.; et al. miR-103/107 Promote Metastasis of Colorectal Cancer by Targeting the Metastasis Suppressors DAPK and KLF4. Cancer Res. 2012, 72, 3631-3641. [CrossRef] [PubMed]

179. Shah, M.Y.; Calin, G.A. MicroRNAs miR-221 and miR-222: A New Level of Regulation in Aggressive Breast Cancer. Genome Med. 2011, 3, 56. [CrossRef] [PubMed]

180. Hwang, M.S.; Yu, N.; Stinson, S.Y.; Yue, P.; Newman, R.J.; Allan, B.B.; Dornan, D. miR-221/222 Targets Adiponectin Receptor 1 to Promote the Epithelial-to-Mesenchymal Transition in Breast Cancer. PLoS ONE 2013, 8, e66502. [CrossRef] [PubMed]

181. Stinson, S.; Lackner, M.R.; Adai, A.T.; Yu, N.; Kim, H.J.; O’Brien, C.; Spoerke, J.; Jhunjhunwala, S.; Boyd, Z.; Januario, T.; et al. miR-221/222 Targeting of Trichorhinophalangeal 1 (TRPS1) Promotes Epithelial-to-Mesenchymal Transition in Breast Cancer. Sci. Signal. 2011, 4, pt5. [CrossRef] [PubMed]

182. Vetter, G.; Saumet, A.; Moes, M.; Vallar, L.; Le Béchec, A.; Laurini, C.; Sabbah, M.; Arar, K.; Theillet, C.; Lecellier, C. miR-661 Expression in SNAI1-Induced Epithelial to Mesenchymal Transition Contributes to Breast Cancer Cell Invasion by Targeting Nectin-1 and StarD10 Messengers. Oncogene 2010, 29, 4436-4448. [CrossRef] [PubMed]

183. Ma, D.; Chai, Z.; Zhu, X.; Zhang, N.; Zhan, D.; Ye, B.; Wang, C.; Qin, C.; Zhao, Y.; Zhu, W. MicroRNA-26a Suppresses Epithelial-Mesenchymal Transition in Human Hepatocellular Carcinoma by Repressing Enhancer of Zeste Homolog 2. J. Hematol. Oncol. 2016, 9, 1. [CrossRef] [PubMed]

184. Liang, H.; Liu, S.; Chen, Y.; Bai, X.; Liu, L.; Dong, Y.; Hu, M.; Su, X.; Chen, Y.; Huangfu, L. miR-26a Suppresses EMT by Disrupting the Lin28B/Let-7d Axis: Potential Cross-Talks among miRNAs in IPF. J. Mol. Med. 2016, 94, 655-665. [CrossRef] [PubMed]

185. Chang, L.; Li, K.; Guo, T. miR-26a-5p Suppresses Tumor Metastasis by Regulating EMT and is Associated with Prognosis in HCC. Clin. Transl. Oncol. 2016, 19, 695-703. [CrossRef] [PubMed]

186. Wang, Y.; Sun, B.; Zhao, X.; Zhao, N.; Sun, R.; Zhu, D.; Zhang, Y.; Li, Y.; Gu, Q.; Dong, X.; et al. Twist1-Related miR-26b-5p Suppresses Epithelial-Mesenchymal Transition, Migration and Invasion by Targeting SMAD1 in Hepatocellular Carcinoma. Oncotarget 2016, 7, 24383-24401. [CrossRef] [PubMed] 
187. Zhang, L.; Wang, Y.; Li, W.; Tsonis, P.A.; Li, Z.; Xie, L.; Huang, Y. MicroRNA-30a Regulation of Epithelial-Mesenchymal Transition in Diabetic Cataracts through Targeting SNAI1. Sci. Rep. $2017,7$. [CrossRef] [PubMed]

188. Peng, R.; Zhou, L.; Zhou, Y.; Zhao, Y.; Li, Q.; Ni, D.; Hu, Y.; Long, Y.; Liu, J.; Lyu, Z. MiR-30a Inhibits the Epithelial-Mesenchymal Transition of Podocytes through Downregulation of NFATc3. Int. J. Mol. Sci. 2015, 16, 24032-24047. [CrossRef] [PubMed]

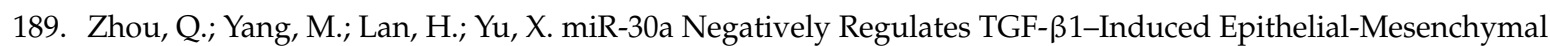
Transition and Peritoneal Fibrosis by Targeting Snai1. Am. J. Pathol. 2013, 183, 808-819. [CrossRef] [PubMed]

190. Wei, W.; Yang, Y.; Cai, J.; Cui, K.; Li, R.; Wang, H.; Shang, X.; Wei, D. MiR-30a-5p Suppresses Tumor Metastasis of Human Colorectal Cancer by Targeting ITGB3. Cell. Physiol. Biochem. 2016, 39, 1165-1176. [CrossRef] [PubMed]

191. Li, J.; Wang, Y.; Luo, J.; Fu, Z.; Ying, J.; Yu, Y.; Yu, W. miR-134 Inhibits Epithelial to Mesenchymal Transition by Targeting FOXM1 in Non-Small Cell Lung Cancer Cells. FEBS Lett. 2012, 586, 3761-3765. [CrossRef] [PubMed]

192. Dong, P.; Kaneuchi, M.; Watari, H.; Hamada, J.; Sudo, S.; Ju, J.; Sakuragi, N. MicroRNA-194 Inhibits Epithelial to Mesenchymal Transition of Endometrial Cancer Cells by Targeting Oncogene BMI-1. Mol. Cancer 2011, 10, 99. [CrossRef] [PubMed]

193. Meng, Z.; Fu, X.; Chen, X.; Zeng, S.; Tian, Y.; Jove, R.; Xu, R.; Huang, W. miR-194 is a Marker of Hepatic Epithelial Cells and Suppresses Metastasis of Liver Cancer Cells in Mice. Hepatology 2010, 52, 2148-2157. [CrossRef] [PubMed]

194. Khella, H.W.; Bakhet, M.; Allo, G.; Jewett, M.A.; Girgis, A.H.; Latif, A.; Girgis, H.; Von Both, I.; Bjarnason, G.A.; Yousef, G.M. miR-192, miR-194 and miR-215: A Convergent microRNA Network Suppressing Tumor Progression in Renal Cell Carcinoma. Carcinogenesis 2013, 34, 2231-2239. [CrossRef] [PubMed]

195. Zhang, L.; Wang, X.; Chen, P. MiR-204 Down Regulates SIRT1 and Reverts SIRT1-Induced Epithelial-Mesenchymal Transition, Anoikis Resistance and Invasion in Gastric Cancer Cells. BMC Cancer 2013, 13, 290. [CrossRef] [PubMed]

196. Qiu, Y.H.; Wei, Y.P.; Shen, N.J.; Wang, Z.C.; Kan, T.; Yu, W.L.; Yi, B.; Zhang, Y.J. miR-204 Inhibits Epithelial to Mesenchymal Transition by Targeting Slug in Intrahepatic Cholangiocarcinoma Cells. Cell. Physiol. Biochem. 2013, 32, 1331-1341. [CrossRef] [PubMed]

197. Sun, Y.; Yu, X.; Bai, Q. miR-204 Inhibits Invasion and Epithelial-Mesenchymal Transition by Targeting FOXM1 in Esophageal Cancer. Int. J. Clin. Exp. Pathol. 2015, 8, 12775-12783. [PubMed]

198. Liu, Z.; Long, J.; Du, R.; Ge, C.; Guo, K.; Xu, Y. miR-204 Regulates the EMT by Targeting Snai1 to Suppress the Invasion and Migration of Gastric Cancer. Tumor Biol. 2016, 37, 8327-8335. [CrossRef] [PubMed]

199. Bendoraite, A.; Knouf, E.C.; Garg, K.S.; Parkin, R.K.; Kroh, E.M.; O’Briant, K.C.; Ventura, A.P.; Godwin, A.K.; Karlan, B.Y.; Drescher, C.W.; et al. Regulation of miR-200 Family microRNAs and ZEB Transcription Factors in Ovarian Cancer: Evidence Supporting a Mesothelial-to-Epithelial Transition. Gynecol. Oncol. 2010, 116, 117-125. [CrossRef] [PubMed]

200. Cheng, W.; Liu, J.; Yoshida, H.; Rosen, D.; Naora, H. Lineage Infidelity of Epithelial Ovarian Cancers is Controlled by HOX Genes that Specify Regional Identity in the Reproductive Tract. Nat. Med. 2005, 11, 531-537. [CrossRef] [PubMed]

201. Zhou, B.; Xu, H.; Xia, M.; Sun, C.; Li, N.; Guo, E.; Guo, L.; Shan, W.; Lu, H.; Wu, Y. Overexpressed miR-9 Promotes Tumor Metastasis Via Targeting E-Cadherin in Serous Ovarian Cancer. Front. Med. 2017, 11, 214-222. [CrossRef] [PubMed]

202. Ye, Z.; Zhao, L.; Li, J.; Chen, W.; Li, X. miR-30d Blocked Transforming Growth Factor Beta1-Induced Epithelial-Mesenchymal Transition by Targeting Snail in Ovarian Cancer Cells. Int. J. Gynecol. Cancer 2015, 25, 1574-1581. [CrossRef] [PubMed]

203. Wu, X.; Ruan, Y.; Jiang, H.; Xu, C. MicroRNA-424 Inhibits Cell Migration, Invasion, and Epithelial Mesenchymal Transition by Downregulating Doublecortin-Like Kinase 1 in Ovarian Clear Cell Carcinoma. Int. J. Biochem. Cell Biol. 2017, 85, 66-74. [CrossRef] [PubMed]

204. Tan, H.; He, Q.; Gong, G.; Wang, Y.; Li, J.; Wang, J.; Zhu, D.; Wu, X. miR-382 Inhibits Migration and Invasion by Targeting ROR1 through Regulating EMT in Ovarian Cancer. Int. J. Oncol. 2016, 48, 181-190. [CrossRef] [PubMed] 
205. Sun, Y.; Hu, L.; Zheng, H.; Bagnoli, M.; Guo, Y.; Rupaimoole, R.; Rodriguez-Aguayo, C.; Lopez-Berestein, G.; Ji, P.; Chen, K. MiR-506 Inhibits Multiple Targets in the Epithelial-to-mesenchymal Transition Network and is Associated with Good Prognosis in Epithelial Ovarian Cancer. J. Pathol. 2015, 235, 25-36. [CrossRef] [PubMed]

206. Zhou, X.; Hu, Y.; Dai, L.; Wang, Y.; Zhou, J.; Wang, W.; Di, W.; Qiu, L. MicroRNA-7 Inhibits Tumor Metastasis and Reverses Epithelial-Mesenchymal Transition through AKT/ERK1/2 Inactivation by Targeting EGFR in Epithelial Ovarian Cancer. PLoS ONE 2014, 9, e96718. [CrossRef] [PubMed]

207. Mezzanzanica, D.; Bagnoli, M.; De Cecco, L.; Valeri, B.; Canevari, S. Role of microRNAs in Ovarian Cancer Pathogenesis and Potential Clinical Implications. Int. J. Biochem. Cell Biol. 2010, 42, 1262-1272. [CrossRef] [PubMed]

208. Meng, X.; Muller, V.; Milde-Langosch, K.; Trillsch, F.; Pantel, K.; Schwarzenbach, H. Diagnostic and Prognostic Relevance of Circulating Exosomal miR-373, miR-200a, miR-200b and miR-200c in Patients with Epithelial Ovarian Cancer. Oncotarget 2016, 7, 16923-16935. [CrossRef] [PubMed]

209. Chung, Y.W.; Bae, H.S.; Song, J.Y.; Lee, J.K.; Lee, N.W.; Kim, T.; Lee, K.W. Detection of microRNA as Novel Biomarkers of Epithelial Ovarian Cancer from the Serum of Ovarian Cancer Patients. Int. J. Gynecol. Cancer 2013, 23, 673-679. [CrossRef] [PubMed]

210. Sohn, E.J.; Won, G.; Lee, J.; Yoon, S.W.; Lee, I.; Kim, H.J.; Kim, S. Blockage of Epithelial to Mesenchymal Transition and Upregulation of Let $7 \mathrm{~b}$ are Critically Involved in Ursolic Acid Induced Apoptosis in Malignant Mesothelioma Cell. Int. J. Biol. Sci. 2016, 12, 1279-1288. [CrossRef] [PubMed]

211. Tang, Z.; Ow, G.S.; Thiery, J.P.; Ivshina, A.V.; Kuznetsov, V.A. Meta-analysis of Transcriptome Reveals Let-7b as an Unfavorable Prognostic Biomarker and Predicts Molecular and Clinical Subclasses in High-grade Serous Ovarian Carcinoma. Int. J. Cancer 2014, 134, 306-318. [CrossRef] [PubMed]

212. Zhou, J.; Gong, G.; Tan, H.; Dai, F.; Zhu, X.; Chen, Y.; Wang, J.; Liu, Y.; Chen, P.; Wu, X. Urinary microRNA-30a-5p is a Potential Biomarker for Ovarian Serous Adenocarcinoma. Oncol. Rep. 2015, 33, 2915-2923. [CrossRef] [PubMed]

213. Vang, S.; Wu, H.; Fischer, A.; Miller, D.H.; MacLaughlan, S.; Douglass, E.; Steinhoff, M.; Collins, C.; Smith, P.J.; Brard, L. Identification of Ovarian Cancer Metastatic miRNAs. PLoS ONE 2013, 8, e58226. [CrossRef] [PubMed]

214. Parikh, A.; Lee, C.; Joseph, P.; Marchini, S.; Baccarini, A.; Kolev, V.; Romualdi, C.; Fruscio, R.; Shah, H.; Wang, F. microRNA-181a has a Critical Role in Ovarian Cancer Progression through the Regulation of the Epithelial-mesenchymal Transition. Nat. Commun. 2014, 5, 2977. [CrossRef] [PubMed]

215. Kinose, Y.; Sawada, K.; Nakamura, K.; Kimura, T. The Role of microRNAs in Ovarian Cancer. Biomed. Res. Int. 2014, 2014, 249393. [CrossRef] [PubMed]

216. Smith, B.; Agarwal, P.; Bhowmick, N.A. MicroRNA Applications for Prostate, Ovarian and Breast Cancer in the Era of Precision Medicine. Endocr. Relat. Cancer 2017, 24, R157-R172. [CrossRef] [PubMed]

217. Venkatraman, A.; He, X.C.; Thorvaldsen, J.L.; Sugimura, R.; Perry, J.M.; Tao, F.; Zhao, M.; Christenson, M.K.; Sanchez, R.; Jaclyn, Y.Y. Maternal Imprinting at the H19-Igf2 Locus Maintains Adult Haematopoietic Stem Cell Quiescence. Nature 2013, 500, 345-349. [CrossRef] [PubMed]

218. Xia, B.; Hou, Y.; Chen, H.; Yang, S.; Liu, T.; Lin, M.; Lou, G. Long Non-Coding RNA ZFAS1 Interacts with miR-150-5p to Regulate Sp1 Expression and Ovarian Cancer Cell Malignancy. Oncotarget 2017, 8, 19534-19546. [CrossRef] [PubMed]

219. Tsai, M.C.; Spitale, R.C.; Chang, H.Y. Long Intergenic Noncoding RNAs: New Links in Cancer Progression. Cancer Res. 2011, 71, 3-7. [CrossRef] [PubMed]

220. Yuan, J.; Yang, F.; Wang, F.; Ma, J.; Guo, Y.; Tao, Q.; Liu, F.; Pan, W.; Wang, T.; Zhou, C. A Long Noncoding RNA Activated by TGF-B Promotes the Invasion-Metastasis Cascade in Hepatocellular Carcinoma. Cancer Cell 2014, 25, 666-681. [CrossRef] [PubMed]

221. Zhou, M.; Sun, Y.; Sun, Y.; Xu, W.; Zhang, Z.; Zhao, H.; Zhong, Z.; Sun, J. Comprehensive Analysis of lncRNA Expression Profiles Reveals a Novel lncRNA Signature to Discriminate Nonequivalent Outcomes in Patients with Ovarian Cancer. Oncotarget 2016, 7, 32433-32448. [CrossRef] [PubMed]

222. Qiu, J.; Lin, Y.; Ye, L.; Ding, J.; Feng, W.; Jin, H.; Zhang, Y.; Li, Q.; Hua, K. Overexpression of Long Non-Coding RNA HOTAIR Predicts Poor Patient Prognosis and Promotes Tumor Metastasis in Epithelial Ovarian Cancer. Gynecol. Oncol. 2014, 134, 121-128. [CrossRef] [PubMed] 
223. Richards, E.J.; Zhang, G.; Li, Z.P.; Permuth-Wey, J.; Challa, S.; Li, Y.; Kong, W.; Dan, S.; Bui, M.M.; Coppola, D.; et al. Long Non-Coding RNAs (LncRNA) Regulated by Transforming Growth Factor (TGF) Beta: LncRNA-Hit-Mediated TGFbeta-Induced Epithelial to Mesenchymal Transition in Mammary Epithelia. J. Biol. Chem. 2015, 290, 6857-6867. [CrossRef] [PubMed]

224. Holm-Nielsen, P. Pathogenesis of Ascites in Peritoneal Carcinomatosis1. Acta Pathol. Microbiol. Scand. 1953, 33, 10-21. [CrossRef] [PubMed]

225. Feldman, G.B.; Knapp, R.C.; Order, S.E.; Hellman, S. The Role of Lymphatic Obstruction in the Formation of Ascites in a Murine Ovarian Carcinoma. Cancer Res. 1972, 32, 1663-1666. [PubMed]

226. Garrison, R.N.; Galloway, R.H.; Heuser, L.S. Mechanisms of Malignant Ascites Production. J. Surg. Res. 1987, 42, 126-132. [CrossRef]

227. Bamberger, E.; Perrett, C. Angiogenesis in Epithelian Ovarian Cancer. J. Clin. Pathol. 2002, 55, 348. [CrossRef]

228. Ueda, M.; Terai, Y.; Kanda, K.; Kanemura, M.; Takehara, M.; Futakuchi, H.; Yamaguchi, H.; Yasuda, M.; NISHKAMA, K.; Ueki, M. Tumor Angiogenesis and Molecular Target Therapy in Ovarian Carcinomas. Hum. Cell 2005, 18, 1-16. [CrossRef] [PubMed]

229. Nagy, J.A.; Herzberg, K.T.; Dvorak, J.M.; Dvorak, H.F. Pathogenesis of Malignant Ascites Formation: Initiating Events that Lead to Fluid Accumulation. Cancer Res. 1993, 53, 2631-2643. [PubMed]

230. Salani, D.; Di Castro, V.; Nicotra, M.R.; Rosano, L.; Tecce, R.; Venuti, A.; Natali, P.G.; Bagnato, A. Role of Endothelin-1 in Neovascularization of Ovarian Carcinoma. Am. J. Pathol. 2000, 157, 1537-1547. [CrossRef]

231. Chen, Y.; Gou, X.; Ke, X.; Cui, H.; Chen, Z. Human Tumor Cells Induce Angiogenesis through Positive Feedback between CD147 and Insulin-Like Growth Factor-I. PLoS ONE 2012, 7, e40965. [CrossRef] [PubMed]

232. Senger, D.R.; Galli, S.J.; Dvorak, A.M.; Perruzzi, C.A.; Harvey, V.S.; Dvorak, H.F. Tumor Cells Secrete a Vascular Permeability Factor that Promotes Accumulation of Ascites Fluid. Science 1983, 219, 983-985. [CrossRef] [PubMed]

233. Neufeld, G.; Cohen, T.; Gengrinovitch, S.; Poltorak, Z. Vascular Endothelial Growth Factor (VEGF) and its Receptors. FASEB J. 1999, 13, 9-22. [PubMed]

234. Geva, E.; Jaffe, R.B. Role of Vascular Endothelial Growth Factor in Ovarian Physiology and Pathology. Fertil. Steril. 2000, 74, 429-438. [CrossRef]

235. Kassim, S.K.; El-Salahy, E.M.; Fayed, S.T.; Helal, S.A.; Helal, T.; Azzam, E.E.; Khalifa, A. Vascular Endothelial Growth Factor and Interleukin-8 are Associated with Poor Prognosis in Epithelial Ovarian Cancer Patients. Clin. Biochem. 2004, 37, 363-369. [CrossRef] [PubMed]

236. Santin, A.D.; Hermonat, P.L.; Ravaggi, A.; Cannon, M.J.; Pecorelli, S.; Parham, G.P. Secretion of Vascular Endothelial Growth Factor in Ovarian Cancer. Eur. J. Gynaecol. Oncol. 1999, 20, 177-181.

237. Garrison, R.N.; Kaelin, L.D.; Galloway, R.H.; Heuser, L.S. Malignant Ascites. Clinical and Experimental Observations. Ann. Surg. 1986, 203, 644-651. [CrossRef] [PubMed]

238. Parsons, S.L.; Lang, M.W.; Steele, R.J.C. Malignant Ascites: A 2-Year Review from a Teaching Hospital. Eur. J. Surg. Oncol. 1996, 22, 237-239. [CrossRef]

239. Rizvi, I.; Gurkan, U.A.; Tasoglu, S.; Alagic, N.; Celli, J.P.; Mensah, L.B.; Mai, Z.; Demirci, U.; Hasan, T. Flow Induces Epithelial-Mesenchymal Transition, Cellular Heterogeneity and Biomarker Modulation in 3D Ovarian Cancer Nodules. Proc. Natl. Acad. Sci. USA 2013, 110, E1974-E1983. [CrossRef] [PubMed]

240. Liu, S.; Zhou, F.; Shen, Y.; Zhang, Y.; Yin, H.; Zeng, Y.; Liu, J.; Yan, Z.; Liu, X. Fluid Shear Stress Induces Epithelial-Mesenchymal Transition (EMT) in Hep-2 Cells. Oncotarget 2016, 7, 32876-32892. [CrossRef] [PubMed]

241. Triantafillu, U.L.; Park, S.; Klaassen, N.L.; Raddatz, A.D.; Kim, Y. Fluid Shear Stress Induces Cancer Stem Cell-Like Phenotype in MCF7 Breast Cancer Cell Line without Inducing Epithelial to Mesenchymal Transition. Int. J. Oncol. 2017, 50, 993-1001. [CrossRef] [PubMed]

242. Aoki, S.; Noguchi, M.; Takezawa, T.; Ikeda, S.; Uchihashi, K.; Kuroyama, H.; Chimuro, T.; Toda, S. Fluid Dwell Impact Induces Peritoneal Fibrosis in the Peritoneal Cavity Reconstructed in Vitro. J. Artif. Organs 2016, 19, 87-96. [CrossRef] [PubMed]

243. Kim, B.G.; Kang, S.; Han, H.H.; Lee, J.H.; Kim, J.E.; Lee, S.H.; Cho, N.H. Transcriptome-Wide Analysis of Compression-Induced microRNA Expression Alteration in Breast Cancer for Mining Therapeutic Targets. Oncotarget 2016, 7, 27468-27478. [PubMed] 
244. Piotrowski-Daspit, A.S.; Tien, J.; Nelson, C.M. Interstitial Fluid Pressure Regulates Collective Invasion in Engineered Human Breast Tumors via Snail, Vimentin, and E-Cadherin. Integr. Biol. 2016, 8, 319-331. [CrossRef] [PubMed]

245. Huang, D.; Liu, Y.; Huang, Y.; Xie, Y.; Shen, K.; Zhang, D.; Mou, Y. Mechanical Compression Upregulates MMP9 through SMAD3 but Not SMAD2 Modulation in Hypertrophic Scar Fibroblasts. Connect. Tissue Res. 2014, 55, 391-396. [CrossRef] [PubMed]

246. Burkhalter, R.J. Microenvironmental Regulation of Ovarian Cancer Dissemination via Activation of the Wnt Signaling Pathway; University of Missouri-Columbia: Columbia, MO, USA, 2012.

247. Gupta, N.; Xu, Z.; El-Sehemy, A.; Steed, H.; Fu, Y. Notch3 Induces Epithelial-mesenchymal Transition and Attenuates Carboplatin-Induced Apoptosis in Ovarian Cancer Cells. Gynecol. Oncol. 2013, 130, 200-206. [CrossRef] [PubMed]

248. Bugide, S.; Gonugunta, V.K.; Penugurti, V.; Malisetty, V.L.; Vadlamudi, R.K.; Manavathi, B. HPIP Promotes Epithelial-Mesenchymal Transition and Cisplatin Resistance in Ovarian Cancer Cells through PI3K/AKT Pathway Activation. Cell. Oncol. 2017, 40, 133-144. [CrossRef] [PubMed]

249. Qin, S.; Li, Y.; Cao, X.; Du, J.; Huang, X. NANOG Regulates Epithelial-Mesenchymal Transition and Chemoresistance in Ovarian Cancer. Biosci. Rep. 2017, 37. [CrossRef] [PubMed]

250. Liu, S.; Sun, J.; Cai, B.; Xi, X.; Yang, L.; Zhang, Z.; Feng, Y.; Sun, Y. NANOG Regulates Epithelial-Mesenchymal Transition and Chemoresistance through Activation of the STAT3 Pathway in Epithelial Ovarian Cancer. Tumor Biol. 2016, 37, 9671-9680. [CrossRef] [PubMed]

251. Roberts, C.M.; Tran, M.A.; Pitruzzello, M.C.; Wen, W.; Loeza, J.; Dellinger, T.H.; Mor, G.; Glackin, C.A. TWIST1 Drives Cisplatin Resistance and Cell Survival in an Ovarian Cancer Model, Via Upregulation of GAS6, L1CAM, and Akt Signalling. Sci. Rep. 2016, 6, 37652. [CrossRef] [PubMed]

252. Zhu, X.; Shen, H.; Yin, X.; Long, L.; Xie, C.; Liu, Y.; Hui, L.; Lin, X.; Fang, Y.; Cao, Y. miR-186 Regulation of Twist1 and Ovarian Cancer Sensitivity to Cisplatin. Oncogene 2016, 35, 323-332. [CrossRef] [PubMed]

253. Lim, S.; Becker, A.; Zimmer, A.; Lu, J.; Buettner, R.; Kirfel, J. SNAI1-Mediated Epithelial-Mesenchymal Transition Confers Chemoresistance and Cellular Plasticity by Regulating Genes Involved in Cell Death and Stem Cell Maintenance. PLoS ONE 2013, 8, e66558. [CrossRef] [PubMed]

254. Chiu, W.; Huang, Y.; Tsai, H.; Chen, C.; Chang, C.; Huang, S.; Hsu, K.; Chou, C. FOXM1 Confers to Epithelial-Mesenchymal Transition, Stemness and Chemoresistance in Epithelial Ovarian Carcinoma Cells. Oncotarget 2015, 6, 2349-2365. [CrossRef] [PubMed]

255. Zhang, X.; George, J.; Deb, S.; Degoutin, J.; Takano, E.; Fox, S.; Bowtell, D.; Harvey, K. The Hippo Pathway Transcriptional Co-Activator, YAP, is an Ovarian Cancer Oncogene. Oncogene 2011, 30, 2810-2822. [CrossRef] [PubMed]

256. Giannakakis, A.; Sandaltzopoulos, R.; Greshock, J.; Liang, S.; Huang, J.; Hasegawa, K.; Li, C.; O’Brien-Jenkins, A.; Katsaros, D.; Weber, B.L. miR-210 Links Hypoxia with Cell Cycle Regulation and is Deleted in Human Epithelial Ovarian Cancer. Cancer Boil. Ther. 2008, 7, 255-264. [CrossRef]

257. Leight, J.L.; Wozniak, M.A.; Chen, S.; Lynch, M.L.; Chen, C.S. Matrix Rigidity Regulates a Switch between TGF-Beta1-Induced Apoptosis and Epithelial-Mesenchymal Transition. Mol. Biol. Cell 2012, 23, 781-791. [CrossRef] [PubMed]

258. Wei, S.C.; Fattet, L.; Tsai, J.H.; Guo, Y.; Pai, V.H.; Majeski, H.E.; Chen, A.C.; Sah, R.L.; Taylor, S.S.; Engler, A.J. Matrix Stiffness Drives Epithelial-Mesenchymal Transition and Tumour Metastasis through a TWIST1-G3BP2 Mechanotransduction Pathway. Nat. Cell Biol. 2015, 17, 678-688. [CrossRef] [PubMed]

259. Bedi, U.; Mishra, V.K.; Wasilewski, D.; Scheel, C.; Johnsen, S.A. Epigenetic Plasticity: A Central Regulator of Epithelial-to-Mesenchymal Transition in Cancer. Oncotarget 2014, 5, 2016-2029. [CrossRef] [PubMed]

260. Wu, C.; Tsai, Y.; Wu, M.; Teng, S.; Wu, K. Epigenetic Reprogramming and Post-Transcriptional Regulation during the Epithelial-mesenchymal Transition. Trends Genet. 2012, 28, 454-463. [CrossRef] [PubMed]

261. Lu, M.; Jolly, M.K.; Levine, H.; Onuchic, J.N.; Ben-Jacob, E. MicroRNA-Based Regulation of Epithelial-Hybrid-Mesenchymal Fate Determination. Proc. Natl. Acad. Sci. USA 2013, 110, 18144-18149. [CrossRef] [PubMed]

262. Tian, X.; Zhang, H.; Xing, J. Coupled Reversible and Irreversible Bistable Switches Underlying TGF $\beta$-Induced Epithelial to Mesenchymal Transition. Biophys. J. 2013, 105, 1079-1089. [CrossRef] [PubMed] 
263. Steinway, S.N.; Zanudo, J.G.; Ding, W.; Rountree, C.B.; Feith, D.J.; Loughran, T.P., Jr.; Albert, R. Network Modeling of TGFbeta Signaling in Hepatocellular Carcinoma Epithelial-to-Mesenchymal Transition Reveals Joint Sonic Hedgehog and Wnt Pathway Activation. Cancer Res. 2014, 74, 5963-5977. [CrossRef] [PubMed]

264. Jia, D.; Jolly, M.K.; Boareto, M.; Parsana, P.; Mooney, S.M.; Pienta, K.J.; Levine, H.; Ben-Jacob, E. OVOL Guides the Epithelial-Hybrid-Mesenchymal Transition. Oncotarget 2015, 6, 15436-15448. [CrossRef] [PubMed]

265. Faddaoui, A.; Sheta, R.; Bachvarova, M.; Plante, M.; Gregoire, J.; Renaud, M.; Sebastianelli, A.; Gobeil, S.; Morin, C.; Ghani, K. Suppression of the Grainyhead Transcription Factor 2 Gene (GRHL2) Inhibits the Proliferation, Migration, Invasion and Mediates Cell Cycle Arrest of Ovarian Cancer Cells. Cell Cycle 2017, 16, 693-706. [CrossRef] [PubMed]

266. Boareto, M.; Jolly, M.K.; Goldman, A.; Pietila, M.; Mani, S.A.; Sengupta, S.; Ben-Jacob, E.; Levine, H.; Onuchic, J.N. Notch-Jagged Signalling can Give Rise to Clusters of Cells Exhibiting a Hybrid Epithelial/Mesenchymal Phenotype. J. R. Soc. Interface 2016, 13. [CrossRef] [PubMed]

267. Li, C.; Hong, T.; Nie, Q. Quantifying the Landscape and Kinetic Paths for Epithelial-Mesenchymal Transition from a Core Circuit. Phys. Chem. Chem. Phys. 2016, 18, 17949-17956. [CrossRef] [PubMed]

268. Li, C.; Wang, J. Quantifying the Underlying Landscape and Paths of Cancer. J. R. Soc. Interface 2014, 11, 20140774. [CrossRef] [PubMed]

269. Cohen, D.P.; Martignetti, L.; Robine, S.; Barillot, E.; Zinovyev, A.; Calzone, L. Mathematical Modelling of Molecular Pathways Enabling Tumour Cell Invasion and Migration. PLoS Comput. Biol. 2015, 11, e1004571. [CrossRef] [PubMed]

270. Zadran, S.; Arumugam, R.; Herschman, H.; Phelps, M.E.; Levine, R.D. Surprisal Analysis Characterizes the Free Energy Time Course of Cancer Cells Undergoing Epithelial-to-Mesenchymal Transition. Proc. Natl. Acad. Sci. USA 2014, 111, 13235-13240. [CrossRef] [PubMed]

271. Chang, H.; Liu, Y.; Xue, M.; Liu, H.; Du, S.; Zhang, L.; Wang, P. Synergistic Action of Master Transcription Factors Controls Epithelial-to-Mesenchymal Transition. Nucleic Acids Res. 2016, 44, 2514-2527. [CrossRef] [PubMed]

272. Tan, T.Z.; Miow, Q.H.; Miki, Y.; Noda, T.; Mori, S.; Huang, R.Y.; Thiery, J.P. Epithelial-Mesenchymal Transition Spectrum Quantification and its Efficacy in Deciphering Survival and Drug Responses of Cancer Patients. EMBO Mol. Med. 2014, 6, 1279-1293. [CrossRef] [PubMed]

273. Ramis-Conde, I.; Drasdo, D.; Anderson, A.R.; Chaplain, M.A. Modeling the Influence of the E-Cadherin-B-Catenin Pathway in Cancer Cell Invasion: A Multiscale Approach. Biophys. J. 2008, 95, 155-165. [CrossRef] [PubMed]

274. Neagu, A.; Mironov, V.; Kosztin, I.; Barz, B.; Neagu, M.; Moreno-Rodriguez, R.A.; Markwald, R.R.; Forgacs, G. Computational Modeling of Epithelial-mesenchymal Transformations. BioSystems 2010, 100, 23-30. [CrossRef] [PubMed]

275. Turner, C.; Kohandel, M. Quantitative Approaches to Cancer Stem Cells and Epithelial-Mesenchymal Transition. Sem. Cancer Biol. 2012, 374-378. [CrossRef] [PubMed]

(C) 2017 by the authors. Licensee MDPI, Basel, Switzerland. This article is an open access article distributed under the terms and conditions of the Creative Commons Attribution (CC BY) license (http:/ / creativecommons.org/licenses/by/4.0/). 